\title{
Chance Encounters: World Literature Between the Unexpected and the Probable
}

Hoyt Long

Hoyt Long, University of Chicago

Peer-Reviewer: Heekyoung Cho, Erik Hayot

Data Repository: 10.7910/DVN/1URBJR

\section{A B S T R A C T}

\begin{abstract}
This essay brings probabilistic reasoning into concerted dialogue with book-historical and sociological approaches to world literature. Using extensive bibliographic data about literary translations into Japanese during the modern era, it develops a series of case studies at interrelated scales - the literary anthology, world library collections, and individual readers - to reason about the likelihood of certain authors or works being plucked from the swirling currents of the global traffic in books. At each scale, I consider how such data might inform the interpretations we give to the choice of one author over another in a given context. Woven into these case studies is an extended reflection on the history of probabilistic reasoning from the late-eighteenth century to the late-twentieth. What, this essay ultimately asks, might literary historians gain from taking this history seriously in our own appeals to chance as a form of historical explanation?
\end{abstract}

The history of modern Japanese literature is also the history of its evolving relation to print culture. ${ }^{1}$ From the late-nineteenth century onward, this relationship came to be mediated by a range of new material interfaces for putting texts in front of reader's eyes, including library reading rooms, mass-market and coterie magazines, newspapers, and low-cost, subscription-based book series. ${ }^{2}$ Among these, the bookstore remained a critical point of first contact, inducing both dreams of universal access to human knowledge and crushing existential angst. The writer Akutagawa Ryūnosuke (1892-1927) famously captured this dynamic in 1927 in a vignette about Tokyo's Maruzen bookstore, long Japan's central hub for imported foreign books. The vignette narrates a scene from his youth in which he takes stock of Maruzen's shelves, inhaling their rarefied air.

It was the second floor of a certain bookstore. Twenty years old, he climbed a Western-style ladder leaning against the shelves, searching 
for new books. Maupassant, Baudelaire, Strindberg, Ibsen, Shaw, Tolstoy...

Soon, dusk fell, yet he continued to read the spines of the books intently. They seemed less a row of books than the fin-de-siecle itself. Nietzsche, Verlaine, the brothers Goncourt, Dostoevsky, Hauptmann, Flaubert...

Fighting the gathering darkness, he listed out their names. But on their own, the books began to sink into the melancholy shadows. He gave up at last and began to climb down the Western-style ladder. Just then, a bare light bulb suddenly clicked on above his head. He stayed on the ladder and looked down at the clerks and customers through the row of books. They seemed strangely small. And so wretched.

'Life cannot compare to a single line of Baudelaire.'

He stayed like this for a time, watching them from atop the ladder..."3

For all the attention this passage has received, commentators have mostly looked past its lists of foreign authors to its allegorical connotations. ${ }^{4}$ It is assumed that the names merely stand in for an ideation of literary modernity and should not be taken as a literal description of what was on Maruzen's shelves. For all we know, Akutagawa was drawing these names randomly from memory. If they have any connection to reality, it is more likely to be with the contents of his personal library than with the purchase orders of Maruzen staff and clientele. But how do we come to this conclusion? With what level of confidence do we say the lists are a random mental projection, or an index of one material reality over another?

To question the probable verisimilitude of these names is to consider the material specificity of literary circulation, but also how this materialization relates to historical ideas of world literature. B. Venkat Mani, expanding on the sociological and book-historical approaches of David Damrosch, Gisèle Sapiro, Priya Joshi, and many others, asserts that engaging with this specificity can "shed new light on the conceptual and ideological creation and proliferation of world literature." It forces literary historians to recognize that the circulation and reception of literature does not happen in a "historical, socio-cultural, or political vacuum," but is rather shaped by patterns of "bibliomigrancy" that impinge on the imagination of world literature 
in specific times and places. These patterns are mediated not just by authors, translators, literary critics, and anthologies, but also "librarians, editors, publishers, literary magazines, book fairs, special interest groups, government censors and promoters, and more recently technological innovations such as electronic reading devices and digital libraries." For Mani, bibliomigrancy brings these multiple determinants under a single term to contend with their complex dynamics and structuring force. It is a call to read more context into any particular imagining of world literature - to read Akutagawa's vision not as the world of literature circa 1910 or 1927, but $a$ world.

But which world? And to whom does it belong? Material and social context are a means to specify the multiple possible worlds of world literature, at least to the extent they are recoverable from the archival record. Yet they do not solve the problem of how to think the historical indexicality of these worlds and their relation to each other. Indeed, Mani himself celebrates a vision of world literature that takes the particularizing force of context to one of its logical terminuses. To wit, he puts great stock in the democratic and liberating potential of Herman Hesse's ideal of world literature as private library and personalized collection. His 1927 essay "A Library of World Literature" dramatically individualizes this ideal such that it is less the overdetermined outcome of impersonal agents and abstract market forces, or of prescriptions by cultural elites, but the contingent result of individual choice and experience: an ideal generated by following "the way of love, not of duty." "There is no single library, Hesse tells us; rather, there are a thousand ways of collecting books." When every instantiation of world literature, every personal library, is as real as any other, the significance of context is diluted. Contingency, by which is meant all the various conditions that impinge on the movement and reception of texts, flips inside out to become total freedom or indeterminacy at the level of the individual. Every response to these conditions seems equally likely because each is no more predictable than any other.

Mani's competing visions of world literature echo an epistemological tension in recent critiques of the "historical/contextualist" paradigm, the canon wars of the 1980s, and even older debates about the role of chance in the determination and preservation of aesthetic value. For Joseph North, the historical/contextualist paradigm is guided by the assumption that "works of literature are chiefly of interest 
as diagnostic instruments for determining the state of the cultures in which they are written or read." $"$ The inverse also holds: the state of the culture and time in which a work is written or read-its context - has the strongest possible bearing on its meaning. Rita Felski has described this paradigm as a process of containment whereby "understanding a text means clarifying the details of its placement in the box [of history], highlighting the correlations and causalities between text-as-object and context-as-container." 10 What this mode of interpretation misses are the "differing and often unpredictable ways" that texts, ideas, and people "disconnect and reconnect" and which are not reducible to the effects of historical and social structures. ${ }^{11}$ It misses, in other words, the variability introduced by the reader, whose "response [to a text] is never entirely predictable or knowable," and who thus contributes to the "hefty dose of serendipity" with which a text does or does not endure beyond its moment of creation. ${ }^{12}$ This aesthetics of chance appears as well in Caroline Levine's New Formalist critique of the contextualist paradigm, wherein she privileges moments when social forms collide and interact in ways counter to their specific affordances and their capacities for organizing other forms. She insists that, "amid the complex and aleatory overlapping of social forms, there are always opportunities for unexpected and ideologically unsettling outcomes."13

Such appeals to the unpredictability of aesthetic response flow readily from the perceived determinism of the historical/contextualist paradigm. The chains of necessity are readily unlocked by the keys of chance, here embodied by individual reader response and the stochastic outcomes of formal collisions. This in itself is not surprising. As Ian Hacking has observed, "necessity and chance are twinned, and neither can exist without the other." Yet "neither explains the other, no more than heads explains tails." ${ }^{14}$ One is needed to think the other, but as idealized models of the world (i.e., a fully determined universe or an inexplicably chancy one) they do not overlap. Appeals to the unexpected need not imply such a dualistic view, but they make it easy to slip into a rhetorical mode that privileges one universe over the other-statistical nihilism over statistical determinism. At their most extreme, they uncannily recall the most vociferous critiques of statistical thinking in mid-to-latenineteenth-century Europe and America. Consider Dostoyevsky's lament in the 1860s that statisticians, for all their intent to "enumerate the good things of life" and for all their love of humanity, always omit one particular thing: "One's own free and unfettered volition, one's own caprice, however wild, one's own fancy, inflamed 
sometimes to the point of madness - that is the best and greatest good, which is never taken into consideration because it will not fit any classification, and the omission of which always sends all systems and theories to the devil." 15

Literary studies is arguably still enmeshed in the epistemological legacy of this prior moment, which saw the "taming of chance" through an elaboration of methods for reasoning between absolute necessity and absolute chance; for imagining a universe where "blind Chance stabilizes into approximate Law"; for reasoning, in a word, probabilistically. ${ }^{16}$ After all, does not appeal to the "unexpected" require that we posit a horizon of possibilities against which expectation is judged? Do we not imply a typical or regular pattern against which the unexpectedness of some aesthetic response, or moment of artistic evaluation, is deduced? All modern academic disciplines came of age under the "empire of chance" that the statistical revolution set into motion, each finding its way toward conceptual and methodological vocabularies for contending with indeterminacy. In literary studies, however, this vocabulary has remained impoverished by comparison, in part because an emphasis on the irreducibility of aesthetic experience and the particularity of individual works (the idiographic) makes it easier to reject regularity or inevitability of any kind (the nomothetic). It is black swans all the way down. And yet if the discipline has, like Dostoyevsky, strongly defended caprice, it has less often reckoned with how its ideas about chance are the historical product of the same taming that has radically reorganized other disciplines. ${ }^{17}$

One motivation for expanding probabilistic reasoning in literary study is the increasing access that digitization has provided to information about the past. Not, however, because this wealth of data more accurately captures the true regularities against which the horizons of chance can be measured. All data is partial and positional and will never say enough about the probability of events as singular as, for instance, the selection of a book for one's personal library of world literature. What an expansion of probabilistic reasoning does offer, I argue, is a richer set of models for reconciling the partiality of data with the partiality of our own subjective judgments and beliefs about the likelihood of an event. For expressing, in other words, these judgments as a matter of degree and not a matter of kind (e.g., necessity and chance). 
Consider another instance of book selection on Maruzen's second floor, this time from novelist Tayama Katai, who recalled his visits to the store around 1901.

It was at that time that I often went with Yanagita Kunio to find and read books like those. Like parched individuals coming to water, we searched through the listings at the back of books and the advertisements at the back of magazines. We'd then spend money we didn't have and order those rare books at Maruzen.

I first came to know Maupassant's name from a short-story collection called Odd Number, which my friend Ueda owned. I subsequently bought Pierre et Jean at a Western booksellers in Nikkō, but at the time no one really knew what kind of writer he was or how he ranked among others. Based on the wholesome stories included in Odd Number, even I thought of him purely as a writer of beautiful short stories that took love as their theme. But of course, while Maupassant did write such things, he was more than that. I soon learned how very different he was from the likes of Daudet.

One day I went to Maruzen's second floor. As was my routine, I flipped through the pages of the books with the largest listings and, by chance, discovered that Maupassant's Short Stories had been published in a cheap series of 10 or 12 volumes. I was thrilled beyond words. I ordered it without thinking about the cost. ${ }^{18}$

To purchase the series, Katai ultimately had to beg for an advance on a travelogue that he had under contract. Cheap and ragged though the books were, he was proud to be the first person in Japan (or so he assumed) to get hold of them. They gave him such pleasure that he remembers, over fifteen years later, "stroking and petting them" upon receipt. ${ }^{19}$ At once a story of personal preference and affective response, wherein Katai's desires are met by the chance appearance of Maupassant's Short Stories amid hundreds of listings, it also hints at specific material and social factors on which this miraculous find was conditioned. A precarious financial situation; a shared interest amongst peers; a broad enough domestic appeal that a provincial bookseller had Maupassant's works in stock (he was the most translated author of the Meiji period, by one estimate); a foreign publishing industry that deemed it profitable to issue his translations in cheap, mass-market form. ${ }^{20}$ What in the act of discovery feels like one of Hesse's thousand pathways seems, with added context 
and in retrospect, to be one of a narrower set of possible outcomes. Not an entirely predictable choice, as if predestined, but also not pure chance.

To reason about Katai's selections from the vast trove of world literature is to find ourselves reasoning probabilistically. How much do we believe his particular experience of world literature stemmed from the freedom of choice idealized by Hesse? How much was it bound by social and material factors that narrowed the range of paths through this trove? Katai knew that "the great waves of thought from the European continent" arrived in Japan in a particular form. Elsewhere he describes "the magnificent scene of Nietzsche's sermons, Ibsen's disobedience, Tolstoy's self, and Zola's dissections making their way into our three-thousandyear-old island temperament... Of course, I don't know whether they initially arrived correctly, or to what degree they were understood, or if they came undistorted and unwarped. At any rate, the fact is that they rushed into our nation's literature...like a kind of violent, awesome gale." ${ }^{21}$ Bibliomigrancy is here figured as a chaotic surge of all manner of thought that leaves trails of debris whose patterns are unpredictable and yet not totally random. This essay asks how quantitative evidence about the literary past can intervene in the ways we reason between this gap at different scales of world literature's materialization.

\section{Between Fate and Chance}

The quantitative evidence I use in this essay is of a basic kind, providing the barest traces of the debris pattern left by Katai's "violent, awesome gale." Basic does not mean simple, however, nor simply obtained. In this case the traces are based on two bibliographic resources that give an account of published translations into Japanese for the Meiji period (1868-1912) and the years 1912-1955. The Meiji period is covered by the Meiji-ki hon'yaku bungaku sōgō nenpyō, a comprehensive bibliography of 4,510 literary translations, including fiction and poetry, published in newspapers, magazines, and individual books. Each entry lists the year of publication and the source author's home country. ${ }^{22}$ The later time span is covered by an 800-page index published by Japan's National Diet Library in 1959. Its nearly 28,000 entries, representing works in all genres by 2,398 foreign authors, include metadata about the author's country of origin, publication year(s), translator, and publisher. ${ }^{23}$ Unlike the Meiji bibliography, this one focuses just on stand-alone 
volumes, including reprints, which makes it blind to the mass of translated material published in general interest and small coterie magazines of the period and biased toward prose fiction. Both resources are mostly blind to literature outside of EuroAmerica and Russia, reflecting the conventional association at this time of "foreign" and "world" literature with the "West."

At this scale of abstraction, there are indeed many reasons to be concerned about the erasures made by these bibliographic traces. For one, differences in medium, genre, and publication context are blurred by the treatment of any translated title as commensurable with any other. Also obscured is the amount of textual traffic occurring via "relay translation," whereby texts were translated from other translations, not the original source language. Nonetheless, insofar as they approximate the relative quantity of material being translated and published, as well as the relative distribution of attention across dominant national literatures and writers, they are a point of first entry into investigating the patterns of bibliomigrancy that structured literary importation and influence in these periods. Taken alone, they can suggest how levels of literary translation fluctuated relative to publication levels overall, highlighting moments of heightened or diminished attention to foreign literatures. 


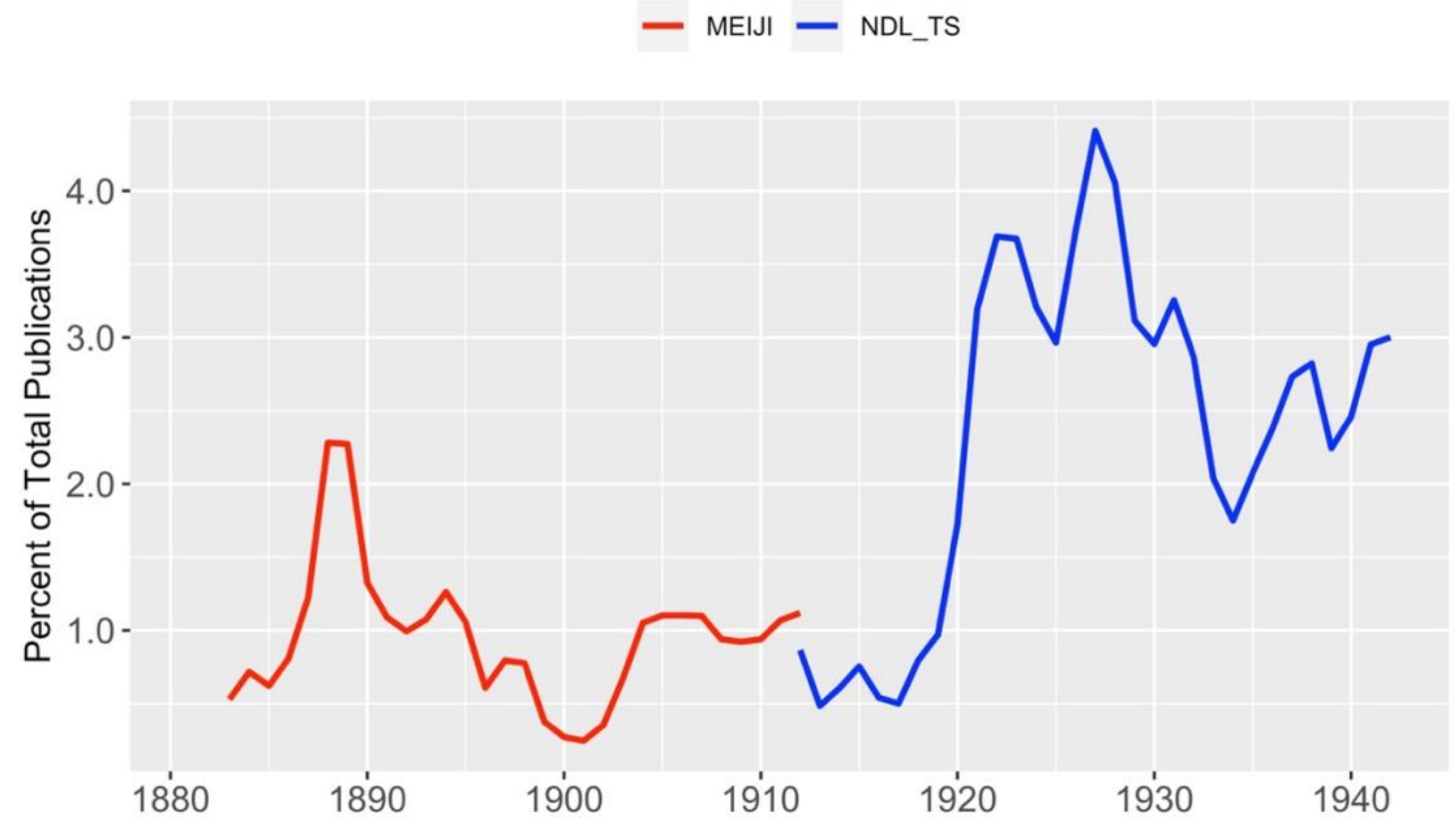

Figure 1: Translations of foreign literature by year as a percentage of overall publication, 1883-1942. "Meiji" refers to the Meiji index, while "NDL_TS" refers to the National Diet Library index.

Figure 1 shows translations as a percentage of total publication from 1883 to $1942 .^{24}$ Here we might notice the considerable dip interrupting the decade of stable rates before 1912 and the sharp rise of the late teens. It would seem to confirm what scholars have written about the chilling of Japan's intellectual climate after the "High Treason Incident" of 1910 and the fears it provoked in government officials about the subversiveness of foreign thought. ${ }^{25}$ These bibliographic traces can also tell a story about how "current" translators and publishers were from year to year in their choice of texts. For instance, when we plot the median birth year of translated authors (Figure 2), we see that they collectively looked further into the past around the same time as the post-Meiji decline, and then again as the Pacific War (and also government censorship) ramped up in the 1940s. Finally, the traces offer a window onto who was most translated or reprinted in certain periods. When translations ebbed from 1913 to 1918, for instance, it was Tolstoy, Goethe, Emerson, and Maupassant who were most translated. Already we see how these data points enrich a historical narrative about the impact of shifting political conditions on the materialization of the world literary imaginary. 


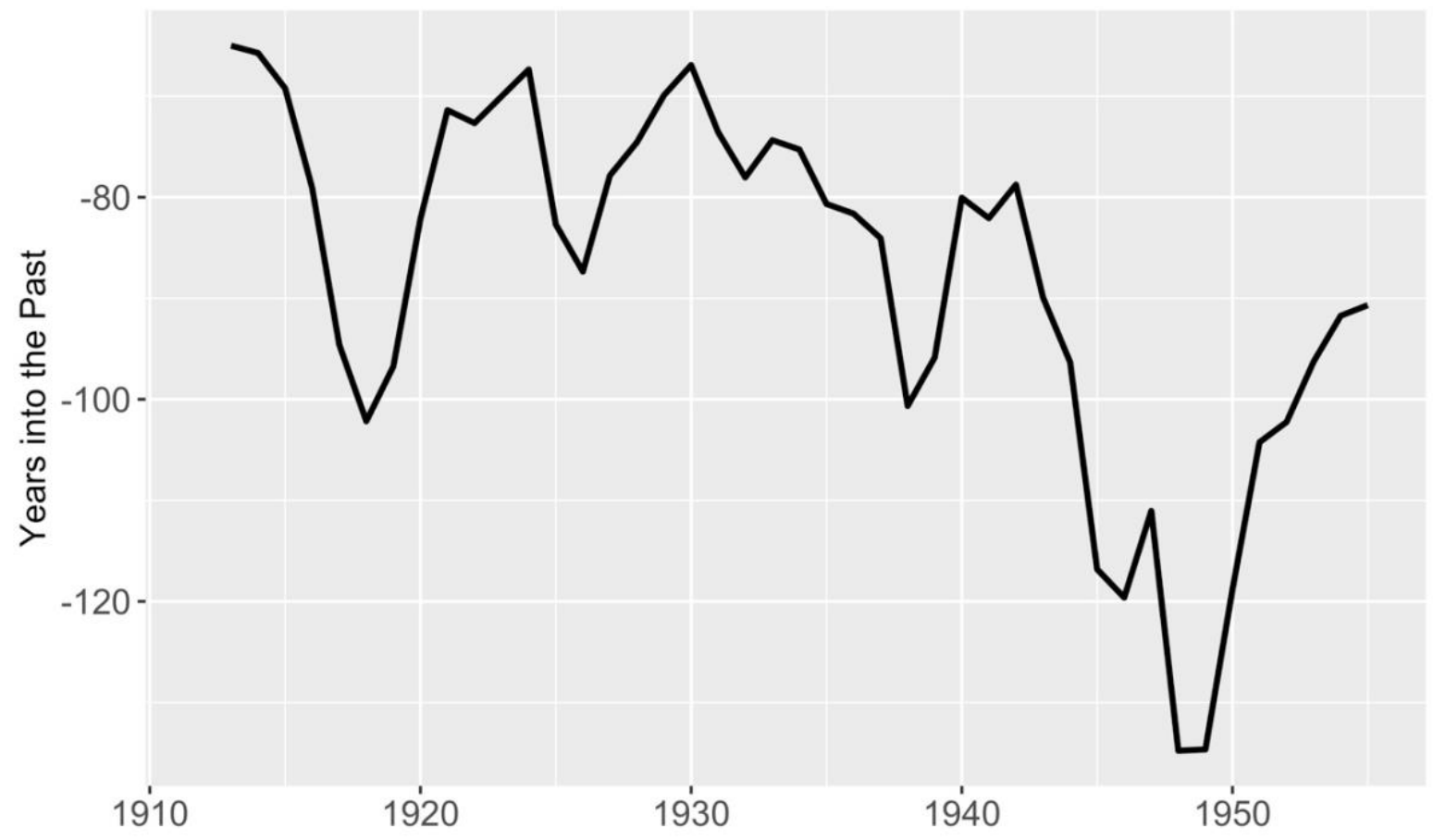

Figure 2: For each year of translation data, the weighted median of author birth years is calculated and subtracted from that year, providing a measure of how "current" translated literature was in that year.

There is nothing novel about using bibliographic traces of this sort to study the circulation of books between languages and national contexts. As early as 1955, the literary historian Ōta Saburō compiled his own dataset from multiple card catalog records to graph fluctuations in the quantity and national origin of literary translations into Japanese.$^{26}$ More recently, book historians and cultural sociologists have argued that quantitative evidence has value for contextualizing acts of translation and consumption because it bridges the gap between the literary and historical, individual social actors and institutional structures, the book as personal experience and commodity form. ${ }^{27}$ These arguments have helped further elucidate how "the poetics of consumption manifest itself through the quantitative record," but they have also struggled with how to hold in suspension the bridge separating event and (numerical) context. ${ }^{28}$ As with Mani, the bridge can morph back into a wall partitioning events and contexts into incommensurable ontologies. Discrete acts of reception, whose determining conditions cannot be fully enumerated nor captured in all their dynamism, become instead icons of indeterminacy and contingency, each miraculous in its own way. Empirical contexts, in contrast, serve to express an 
underlying structure or order, yet their necessary abstractions render their relation to particular events diffuse. One can think the event and liberate subjectivity with appeals to inexplicable chance; or one can think context while appealing to objectivity and causal explanation. But how to think the relation between them?

How to relate future discrete event to underlying context is a question at the heart of philosophical debates around the taming of chance. As Lorraine Daston and other historians have shown, the story of this taming is one of shifting ideas about the certainty with which we can say that an event or outcome will come to pass (e.g., a coin toss, a shipwreck, a suicide). Probability is at root a science for reasoning about the limits of human knowledge. The taming of chance, which continues today, is simultaneously a story of how the subjective beliefs informing this reasoning came to be superseded by the assumed objectivity of numbers and the natural or social regularities "discoverable" in statistical data even as the empire of chance expanded from the domain of games and parlor tricks to insurance, law, medicine, and eventually to most academic disciplines. ${ }^{29}$ At every stage methodologists and applied practitioners have hotly debated the proper purview of probabilistic reasoning, debates that play out now against the background of predictive algorithms that threaten to reinforce and amplify existing social hierarchies. ${ }^{30}$

I am interested in these historical debates as a reservoir for conceptualizing the relation of event to context, and present contingency to past knowledge. Literary historians have been reluctant to tap this reservoir, in part due to an insistence on the irreducible complexity and uniqueness of the phenomena we study. The reservoir's depths are too readily distilled into caricatures of its epistemological extremes, and indeed, as Eric Hayot writes, must be so distilled in order to preserve the conditions for the "restricted, self-enclosed existence" that may give "humanist ethos and scientific desire their deepest meaning" but which is also a kind of imprisonment. ${ }^{31}$ At one extreme is the idea of probability as a totalizing and deterministic concept that sees every event as predictable with enough statistical data; and on the other a radical skepticism that sees uncertainty everywhere and is in fact a romantic (and later post-structural) backlash to the first position. But the waters of this reservoir, as Maurice Lee writes, are actually far murkier: "Even nineteenth-century probability experts vacillated between competing models of chance: objective views (actual probabilities in nature) versus subjective ones (expectations under conditions of partial knowledge); descriptions of past events versus predictions of future ones; 
degrees of belief regarding single outcomes versus the mass logic of frequentism (an approach that eventually came to dominate the field but emerged unevenly over the century)." 32

Chance has always been a slippery notion, made no less so by its encounter with mathematics in the eighteenth-century, statistics in the nineteenth and twentieth, and large-scale predictive algorithms today. But we miss a great deal when we reduce all the ways it has been reasoned about to two camps or fail to reflexively situate our own thinking as a byproduct of this history. Here I will dredge up some of the conceptual language of past approaches to probability and apply them to the discrete acts of selection and evaluation that add up to the broad flows and patterns of bibliomigrancy. I view these acts of selection through three frames, beginning with anthologies of world literature, moving to global trends in library acquisition, and then zooming back to the individual choices of translators and readers. With each frame I use past forms of probabilistic reasoning to reason across the gap between event and context and thereby expand the ways we have of thinking about the unexpected.

\section{Probable Causes}

Thus far my only frame has been the singular act of plucking, whether via memory or purchase order, a book from store shelves, which feels as if one is looking at the vast currents of bibliomigrancy through the eye of a needle. Their discreteness, however, makes these acts useful thought experiments. They are funnels of time and possibility, controlling the flow of what comes before and what follows, like the neck of an hourglass. At the point where infinite paths narrow to a single decision before expanding out again, we can begin to reason about how probable was Katai's choice of Maupassant, or Akutagawa's singling out of Baudelaire. Literary historians and statisticians alike will likely say it is impossible to predict, though their explanations for this impossibility would differ. The former might lean on the subjective nature of aesthetic experience, as does Barbara Herrnstein Smith in her classic study, Contingencies of Value. There she frames the experience of aesthetic objects as a matter of "personal economy," arguing that the "features," "qualities," 
or "properties" of aesthetic objects are "the variable products of the subject's engagement with his or her environment under a particular set of conditions." These conditions are linked to material processes, cultural practices, and human needs, all continuously transformed and redirected with each new encounter. ${ }^{33}$ With so many dynamic variables in play, the odds that a given book or author is chosen at a particular moment seems a matter of random chance. As predictable, to paraphrase David Hume, as a miracle. ${ }^{34}$

Smith's argument, which aims to destabilize Kantian notions of intrinsic aesthetic value, ends at a critique of predictability itself. She concludes that there is "no way for individual or collective choices, practices, activities, or acts, 'economic' or otherwise, to be ultimately summed-up, compared, and evaluated: neither by the single-parameter hedonic calculus of classical utilitarianism, nor by the most elaborate multiple-parameter formulas of contemporary mathematical economics nor by any mere inversion or presumptive transcendence of either." ${ }^{35}$ The easy conflation of individual with collective choices allows Smith's critique to land more forcefully than it might otherwise, but it is worth pausing to consider whether the whole history of probabilistic reasoning can be summed-up in this way. In fact, when it comes to individual choices and events, much of nineteenth-century statistics was built on the idea that there was nothing to learn from them at all - that predictability came from regularities across large numbers of similar events, not individual variation. In considering Katai's predilection for Maupassant, a frequentist approach would insist on richer data about, for instance, the purchasing habits of aspiring Japanese writers at the turn-of-the-century. Where Smith sees far too many variables to precisely model an aesthetic response, a frequentist sees too little comparable information to be certain in much of anything. For both, the ability to infer the cause of Katai's selection is impeded by different kinds of ignorance about the world.

The problem of how to assess one's degree of ignorance about the world and square it with experience or observation has been at the heart of probabilistic reasoning since its emergence as a calculus of moral judgment and reason. I revisit these origins and their metaphorics now to replay my running thought experiment in a classical key. A canonical metaphor from probability's classical period is the urn model of causation, first articulated by the mathematician Jakob Bernoulli (1655-1705). To wit, "imagine an urn filled with colored balls in some fixed proportion, from which 
repeated drawings with replacement are made....The fixed but unknown proportion of balls in the urn corresponds to the hidden causes, and the results of the repeated drawings to the observed effects." ${ }^{36}$ Bernoulli developed a theorem to specify the number of drawings necessary to insure that the ratio of colored balls drawn "falls within a certain margin of the true ratio with a given probability." 37 That is, it guaranteed that in the long run, the ratio of observed frequencies will converge to the "true" hidden ratio. The theorem also put a precise number on how many observations warranted what degree of certainty about this ratio. While the number turned out to be far too large to be meaningful in practical terms, the urn metaphor helped to expand the "art of conjecture" beyond games of chance, for which calculations of probability generally assumed equally possible outcomes (e.g., rolling dice), to "more complex and interesting situations like human diseases and the weather." 38 It expressed a relation between hidden causes and observed effects such that the underlying mechanisms producing a given phenomenon could be ignored as their effects necessarily replicated their true, proportional influence on that phenomenon. More important was being able to assess one's degree of ignorance about this true ratio, whose truth was ultimately determined by God.

Bernoulli's model was roundly critiqued for its problematic assumptions about the stability of causes, especially as these assumptions pertained to moral, as opposed to natural, laws. Leibniz, for instance, took aim at the model's naive simplicity: "What if the mix of balls contained in the urn changed with time? What if the number of balls were infinite? What if no determinate ratio existed among the various types of balls?" 39 He was thinking specifically of its inadequacy for investigating illness. How could such a model possibly represent the innumerable diseases that affect the body in unknown proportions of deadliness. Running the bookstore scene through this model, as if Katai were drawing from an urn of colored balls representing multiple authors in varying proportions, we similarly confront the model's problematic assumptions. Surely his choice of Maupassant does not depend solely on the proportion of works by him, Tolstoy, Zola, or other writers in circulation at the time. Nor can we assume that these proportions were stable. Even if they were, there is no reality in which Katai repeats his selection enough times that we can reliably measure our ignorance of these proportions. All models are wrong, of course, but this one feels especially wrong for the case at hand. Yet the fantasy of having Katai choose over and over again, and the hypothetical question of whether 
his choices converge to some ratio reflective of external determinants, begs the question of what we as literary historians might imagine to fill this metaphorical urn. What past causes are hidden inside, and which weigh the heaviest on future effects? If we could watch a hypothetical Katai repeatedly draw from this urn, how would our beliefs about these underlying probabilities change with each observation? How, that is, does our sense of an event's likelihood shift with how much we know about the past?

Putting Katai's singular act on repeat pushes this thought experiment to its breaking point, but we can take it one step further. Indeed, the theoretical limits of Bernoulli's infinite draws are precisely what sparked a conceptual breakthrough in probabilistic reasoning, shifting attention from the probability of observed frequencies given a true, underlying ratio to the inverse calculation: given some observed frequency, how likely is it to be an approximation of the unknown ratio or probability. "Or, as the problem was more often posed, given that an event has occurred so many times before, what is the probability that it will occur again on the next trial? In short, what is the probability that the future will be like the past?" 40 The calculus of such "inverse probabilities" was first pursued by Thomas Bayes (1702-1761) and subsequently refined by Pierre-Simon Laplace (1749-1827). Bayes's crucial insight was to turn probability into a measure of informed belief - a measure updated with each new observation of a phenomenon. Lacking perfect knowledge of causes, he reasoned, why not begin with the limited knowledge one has and judge the probability of an outcome based on this initial ignorance. Assuming the causes are constant, one can successively update this judgment as new knowledge arrives, thus providing an increasingly precise measure of the limits between which it is reasonable to believe that the true probability lies. ${ }^{41}$ Laplace would expand these ideas into a general method for inferring the most likely cause of an event from all possible causes (e.g., the colors of balls in the urn). He did so in part by intuiting that the probability of a cause (given an event) is proportional to the probability of the event (given its cause). ${ }^{42}$ But he also followed Bayes in insisting that "probabilists must continually correct their estimates of relative possibilities in light of new knowledge concerning absolute possibilities," where "relative" corresponded to initial guesses based on ignorance and "absolute" corresponded to estimates based on actual observations. ${ }^{43}$ By 1814 he arrived at the equation known today as Bayes' rule, the cornerstone of Bayesian statistical inference. ${ }^{44}$ 
I am less interested in the specifics of this rule and its practical applications (Laplace used it to estimate the accuracy of astronomical observations, male/female birth ratios, and jury decisions) than the inferential step that injects a subjective guess into its mathematical machinery. Replaying our thought experiment through this logic of inverse inference, we are forced to confront our own initial guesses — our estimates of "relative possibilities" - regarding the likelihood of Katai drawing Maupassant. Or if these feel too hard to pin down amid the waves of personal whim and past experience, we can shift the frame of reference to acts of book selection with seemingly more stable social coordinates: editorial decisions by compilers of literary anthologies. What happens to our initial guesses about the likelihood of this or that author when our thought experiment moves from the bookstore to the publishing house? And specifically to the publisher Shinchōsha, who began releasing its Anthology of World Literature (Sekai bungaku zenshū) in 1927. If Maruzen was a central clearinghouse of foreign literature for aspiring and elite writers, this anthology was the gateway for the masses. Released in two separate stages (Part Two began publication in 1930), the anthology totaled fifty-seven volumes in all and was part of the enpon (one-yen) book boom that saw the rise of a competitive market for cheap, multi-volume series of modern great books, older classics, and less highminded collections for the masses. Shinchōsha's series emerged a clear winner, selling more than 400,000 complete sets as compared with rival Kaizōsha's "modern Japanese literature" series, which sold just 250,000. ${ }^{45}$ Beyond Japan, it paralleled developments in British and American commercial publishing that from the 1890s saw the confluence of the "scholarly list" mode with the mass-market "enterprising" mode to produce the "patriarchal capitalist" mode, which produced series like Routledge's "World Library," "World Classics" by Oxford University Press, and J.M. Dent's "Everyman Library for Young People," created in 1905 with the ambition to publish 1,000 great works. ${ }^{46}$ By reducing an infinite sea of texts to a curated selection, these series aimed to educate the masses and keep the lay reader "out of the grog shop or away from newspapers." 47

The Shinchōsha anthology's affinity with the patriarchal capitalist mode is made clear in a two-page newspaper ad that equated it, in content and cost, to Everyman's Library. ${ }^{48}$ This was pure salesmanship in terms of the actual number of works, but Part One of the anthology includes many of the same authors and titles. Dante, 
Goethe, Milton, Shakespeare, and Cervantes were there to represent the classics; Hugo, Balzac, Dickens, Flaubert, Maupassant, Tolstoy, Turgenev, Dostoevsky, Poe, and Hawthorne stood in for the nineteenth-century novel; Chekov, Gorky, Maeterlinck, Ibsen, and Hamsun, among others, added more contemporary fare (Table 1). ${ }^{49}$ Series editor, Satō Giryō, also framed the anthology as part pedagogical and part civilizing mission, touting it as a "giant textbook for the study of humanity" and "a necessary qualification for being a global citizen." ${ }^{50}$ But the masses were not the only market that he and Shinchōsha were after. Or rather, they knew that the works had to appeal just as much to those writers and intellectuals who could confer on them the necessary cultural capital. When the prominent political theorist Yoshino Sakuzō authored a promotional piece in the Tokyo Daily Newspaper (Tokyo nichinichi shinbun), he quoted a friend who, upon seeing the two-page ad, exclaimed that every title, to the very last one, was "food for the soul and a work that should always be close at hand. I want them all so bad I'm ready to rush out and get them." 51 This was a textbook for the masses as much as an ornament displaying that one had absorbed the lessons contained therein.

\begin{tabular}{|l|l|}
\hline Author & Translated Work(s) \\
\hline Dante & Divine Comedy \\
\hline Boccacio & Decameron \\
\hline Shakespeare & Hamlet, Romeo and Juliet \\
\hline Cervantes & Don Quixote \\
\hline Milton & Paradise Lost \\
\hline Walter Scott & Ivanhoe \\
\hline Rousseau & Confessions \\
\hline Goethe & Faust \\
\hline Poe & Selections \\
\hline Nathaniel Hawthorne & Scarlet Letter \\
\hline Victor Hugo & Les Miserables \\
\hline Alexandre Dumas & Count of Monte Christo \\
\hline Balzac & Selections from The Human Comedy \\
\hline Charles Dickens & Tale of Two Cities \\
\hline
\end{tabular}




\begin{tabular}{|l|l|}
\hline Emile Zola & L'Assommoir \\
\hline Flaubert & Madame Bovary \\
\hline Guy de Maupassant & A Woman's Life \\
\hline Ivan Turgenev & Fathers and Sons, Virgin Soil \\
\hline Dostoyevsky & Crime and Punishment \\
\hline Tolstoy & Resurrection \\
\hline Chekhov & Selections \\
\hline Maxim Gorky & Selections \\
\hline Sienkiewicz & Quo Vadis \\
\hline Henrik Ibsen & Selections \\
\hline Bjornson & Selections \\
\hline Knut Hamsun & Hunger \\
\hline Strindberg & Confessions of a Fool, Dance of Death \\
\hline Thomas Hardy & Tess of the D'urbervilles \\
\hline Joseph Conrad & Selections \\
\hline D'annunzio & Triumph of Death \\
\hline Daudet & Sappho \\
\hline Hauptmann & Selections \\
\hline Maurice Maeterlinck & Monna Vanna \\
\hline Schniztler & Selections \\
\hline Anatole France & Thais, Crainquebille \\
\hline Henri Barbusse & Hell \\
\hline Charles Phillipe & Bubu of Montparnasse \\
\hline Bernard Shaw & Selections \\
\hline John Galsworthy & Selections \\
\hline Synge & Selections \\
\hline Rostand & Cyrano de Bergerac \\
\hline Romain Rolland & The Wolf \\
\hline
\end{tabular}

Table 1: Authors and works anthologized in part 1 of Anthology of World Literature.

Such paratextual evidence already constrains initial guesses about the likelihood of specific authors appearing in the anthology. It allows us to situate these guesses within a set of possible editorial intentions and strategies. For instance, we might situate them in Bourdieu's familiar notion of a "dual discourse," which argues that the democratization and mass production of a culture's "classics" is always partly an opening up of knowledge only after it is "permitted, authenticated and ultimately cheapened by the upper strata, whether these are the aristocrats and officials who 
endorse the books or the professionals and intellectuals who edit and publish them." $" 52$ This might raise in our minds the weight of older, already canonized authors and works and, depending on our ideas about the canon, make Goethe, Maupassant, or Tolstoy feel more or less predictable. Digging deeper into the historical context might unearth more prosaic rationales behind these editorial choices, prompting us to revisit our initial guesses. As Mary Hammond observes about Oxford's "World Classics" series, whether a work was out of copyright and cheap to acquire, its length suitable to the series' format, and its content inoffensive to lower and middle-class readers often took precedence over aesthetic merit or canonical recognition. In the case of Shinchōsha, it had been acquiring and publishing literary translations for a decade, and more than $60 \%$ of the titles in Part One appeared in earlier formats. ${ }^{53}$ Moreover, Satō was adamant about including works he deemed highly legible to mass audiences, taking extra steps to edit each translation for clarity even if it had previously been published. ${ }^{54}$ Such evidence is bound to shift our calculus of probabilities yet again, increasing our certainty about Satō's selections relative to his immediate context while making them look increasingly contingent relative to larger patterns of bibliomigrancy. The more we contextualize his path through world literature, the more it feels like one in a thousand. But at what point do we begin to say this path is random or unexpected?

At issue here is how the perception of chance varies with contextual clues. How do we convince ourselves that Satō's path was more or less random? And relative to what? As literary historians, we often use contextual clues to explain away variation and hone our estimates of what seems most likely or probable. As strict Bayesians, we would start from a decidedly more naïve position. For both Bayes and Laplace, in fact, the safest initial hypothesis in the absence of any observational evidence was to assign equal probability to every possible cause (e.g., if it was our first day on Earth, we would say that the sun is as likely to rise tomorrow as not). This "uniform prior probability" constituted an initial baseline to be updated with each new observation until it more closely approximated the true underlying probability of an event (e.g., the sun always rises). Applied to our thought experiment, we could start with the assumption that every foreign author was as likely to be selected by Satō for the Shinchōsha anthology as any other (i.e., each was represented by the same number of colored balls in the imaginary urn). This seems absurd, of course, not least because we cannot watch Satō draw successive balls from this urn and thus 
have no way of updating our beliefs about its composition. Yet what if we imagined his draws not as a starting point but as an endpoint in a long succession of picks by Shinchōsha and other publishers from the same urn? How probable do his selections look in light of the many selections made before him?

In positing this scenario, I understand that the probabilistic calculus I am asking for is not formally viable. ${ }^{55}$ My point is to ask how bibliographic data can be reframed as evidence that can inform our subjective guesses about chance. Before tethering it to an objective historical reality, as might be the initial impulse, what if we regard it as evidence for updating our prior beliefs? Against this revised baseline, how unexpected do Satō's choices look? Sticking with the urn metaphor, I represent this evidence as the proportion of translated works by each author for a given period. In the National Diet Library dataset, there are 5,892 titles representing 749 unique authors translated between 1912 and 1927. Filtering out authors with one title leaves 400 authors. Figure 3 visualizes their proportional representation across the period, colored by whether they were included in Shinchōsha's anthology or not. All included authors are labeled, in addition to the top 50 most translated overall. As a measure of the past attention given to an author, proportion leaves a lot to be desired. Were such data available, we might re-weight these circles according to the ages of the authors, their total output, or the size of print runs, thus leveling out the natural advantages afforded authors who had more works to be translated or correcting for low counts belying a work's actual success in the marketplace. Even with this simplistic representation, however, we can begin to reason differently about Satō's editorial decisions. 


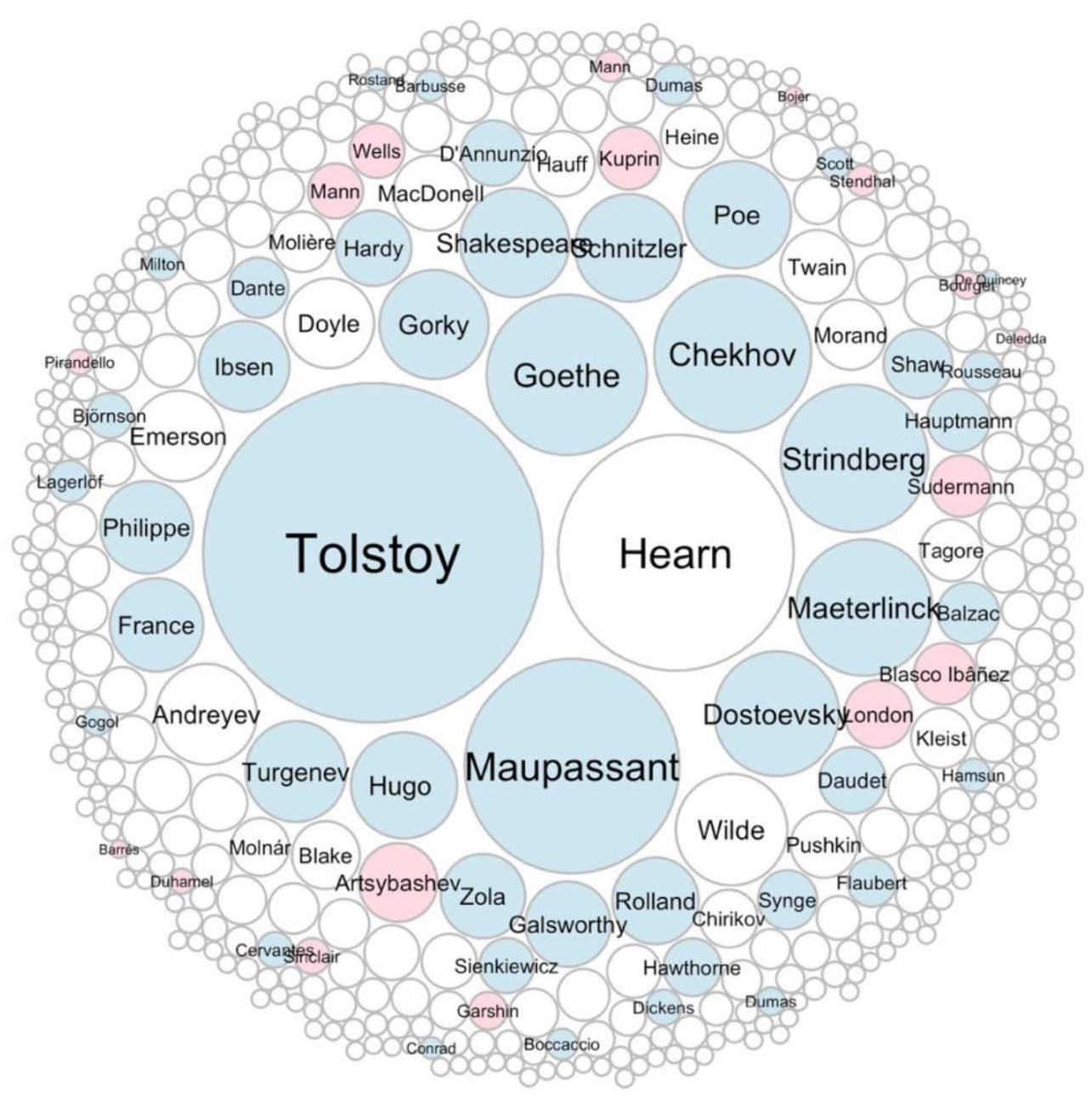

Figure 3: Proportional representation of all translated authors from 1912 to 1927. Blue indicates inclusion in Part One of the anthology; red indicates inclusion in Part Two; and white means an author was not included.

Note that a majority of the colored circles are also the largest, suggesting that prior prominence in the market raised the likelihood of an author's selection. Many of Satō's choices look rather conventional in light of past evidence. Other choices look surprising by contrast. The smaller colored circles at the outer edges highlight cases where the motivations for inclusion were driven by more than just market success or availability. The choice of Norwegian novelist Johan Bojer (1872-1959), for instance, seems highly idiosyncratic and unexpected in light of past publications. What was motivating his inclusion? Also surprising is the choice to exclude authors at the center of the figure. Why not grant to Leonid Andreyev (1871-1919) or Pushkin (1799-1837) the same level of recognition as their equally popular countrymen? The figure itself provides no answers, but it does frame further 
qualitative inquiry in ways different than had we started with other evidence (e.g., information about individual authors, our preconceptions of the world literary canon). These would have biased in other ways our reasoning about the probability, and also conventionality, of Satō’s selections.

Just as the bibliographic data helps us reason about these selections with respect to the past, it also allows us to reason about their relation to future trends. If some choices appear more conventional or unexpected at the time of anthologization, what about when viewed in retrospect? Do they look like clever foresight or ill-timed wagers? To do this, let us imagine each author's record of translation into Japanese as a temporal trend line, where for each year in the dataset we calculate the percentage of total translations attributed to an author. These individual trend lines can then be aggregated, showing how much collective attention is given to a set of authors by the publishing market each year. For instance, authors can be grouped by which part of the anthology they were included in, since the editorial calculus differed slightly for each part. Authors selected for Part One tended to be older, canonical figures, with a median birth year of 1836. Authors chosen for Part Two skew younger, with a median birth year of 1876. For this second installment of the anthology, Satō placed bets on authors like Jack London, Upton Sinclair, Aldous Huxley, Thomas Mann, and Leonid Leonov, all relatively new to the translation market. By plotting the trend for individuals or aggregate groups we can determine if the moment of anthologization marked a break with past and future trends. Did it add to the weight of past contingent decisions or was it the first to tip the scale?

We can assess the presence of such temporal breaks using the Chow Test, which indicates whether linear models fit to subsets of a sample (i.e., the trend lines before and after a specified break point) perform differently from one another and from the trend line as a whole. A significant result $(\mathrm{p}<.05)$ means that the two subsets perform differently enough to provide evidence of a "structural break" in the data and a lack of continuity. ${ }^{56}$ Here I apply this test to the trend lines (calculated as a moving average of the percent of all translations) for authors in the anthology, and the aggregate trend lines of all authors in each part, using 1929 as the break point for Part One and 1932 for Part Two. The results and corresponding p-values are displayed in Figures 4 through 7. Across the results for individual authors, four distinct patterns emerge: 1) Authors steadily or increasingly translated until 
anthologization but less so after (Tolstoy, Chekhov, Shakespeare, Strindberg); 2) Authors steadily or increasingly translated even after anthologization (Maupassant, Dostoevsky, Poe, Balzac); 3) Authors minimally translated prior to anthologization but more so afterward (Mann, Stendhal); and 4) Authors shown some interest beforehand but very little after (London, Kuprin, Sinclair). This typology provides a set of entry points for investigating how the anthology did (and did not) serve as an inflection point in the consecration of aesthetic value for these authors, informing hunches about the social impact of anthologization.
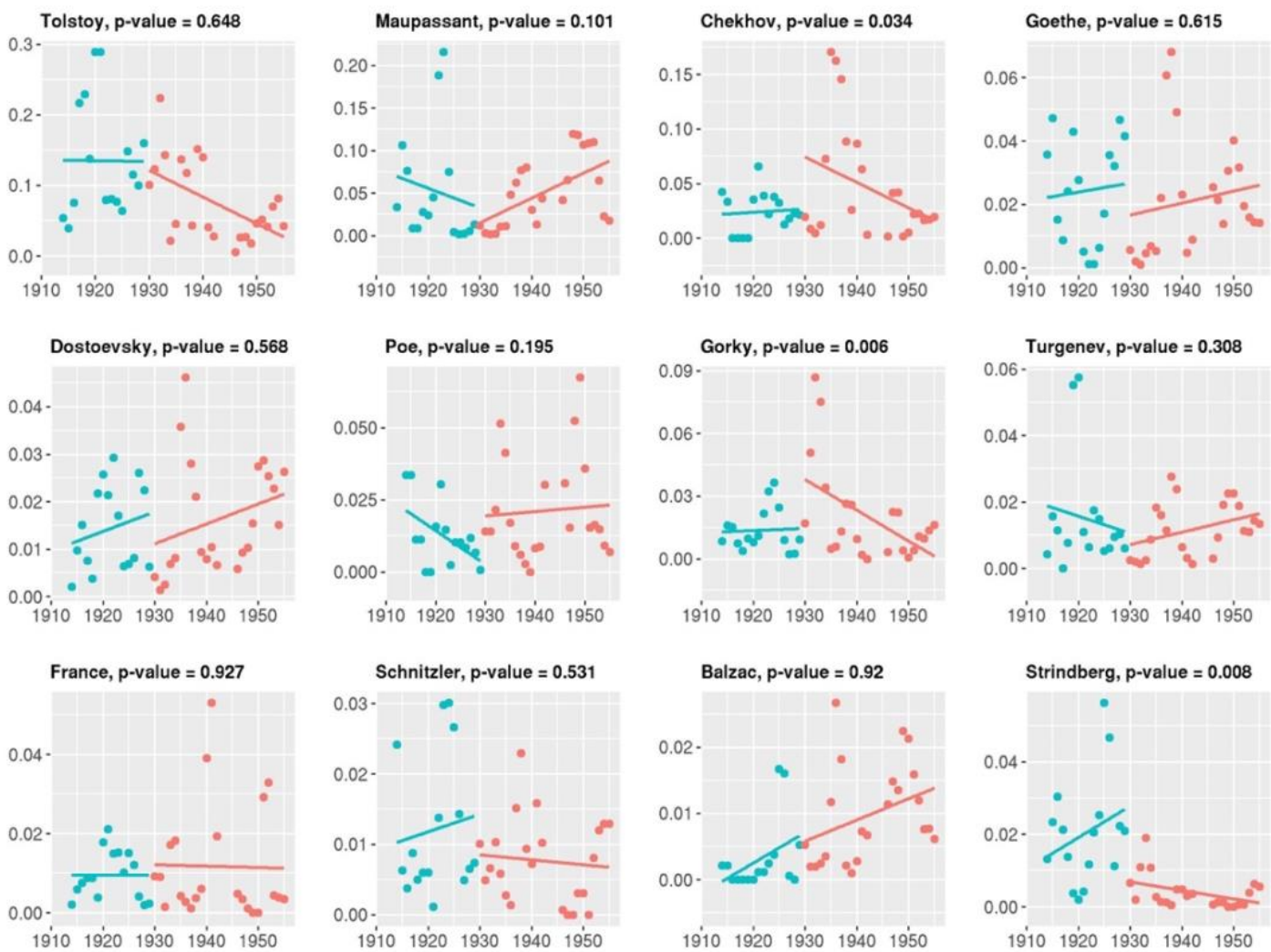

$19 \dot{10} \quad 1920 \quad 1930 \quad 19 \dot{4} 40 \quad 1950$

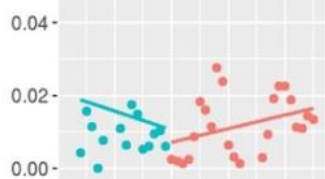

$1910192019301940 \quad 1950$
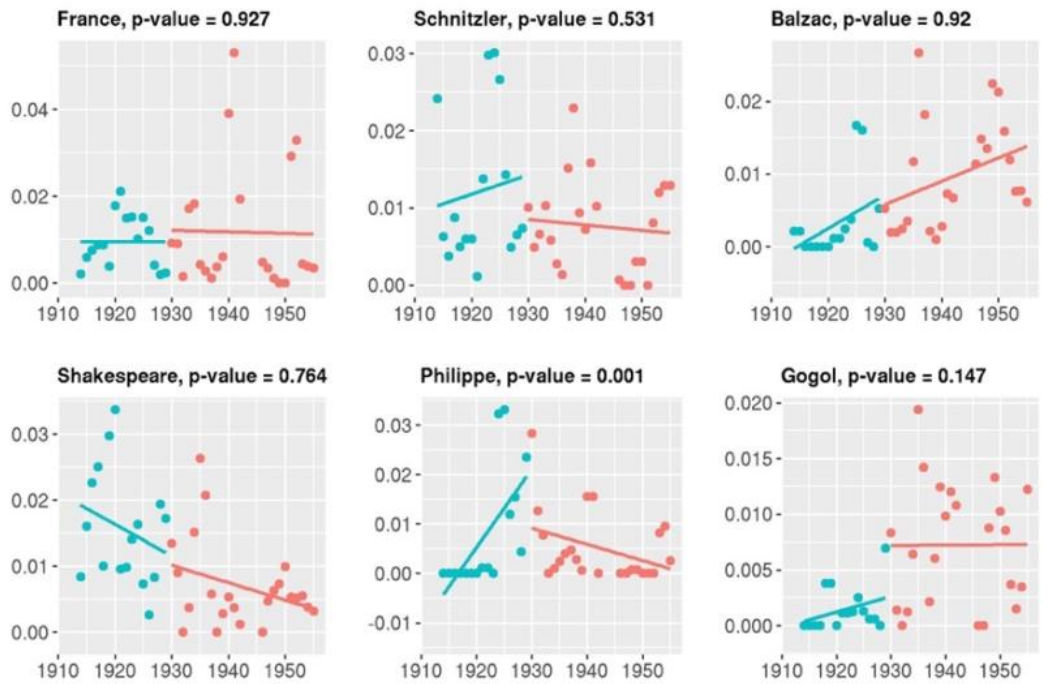

$\begin{array}{lllll}19 \dot{1} 10 & 1920 & 1930 & 19 \dot{4} 40 & 1950\end{array}$
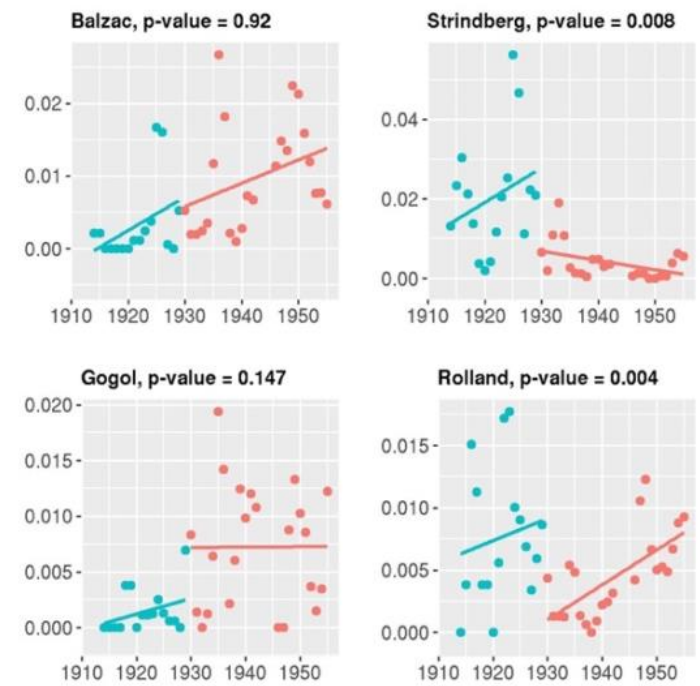

Figure 4: Chow Test plots for 16 most translated authors in Part One, ranked right to left, top to bottom. 

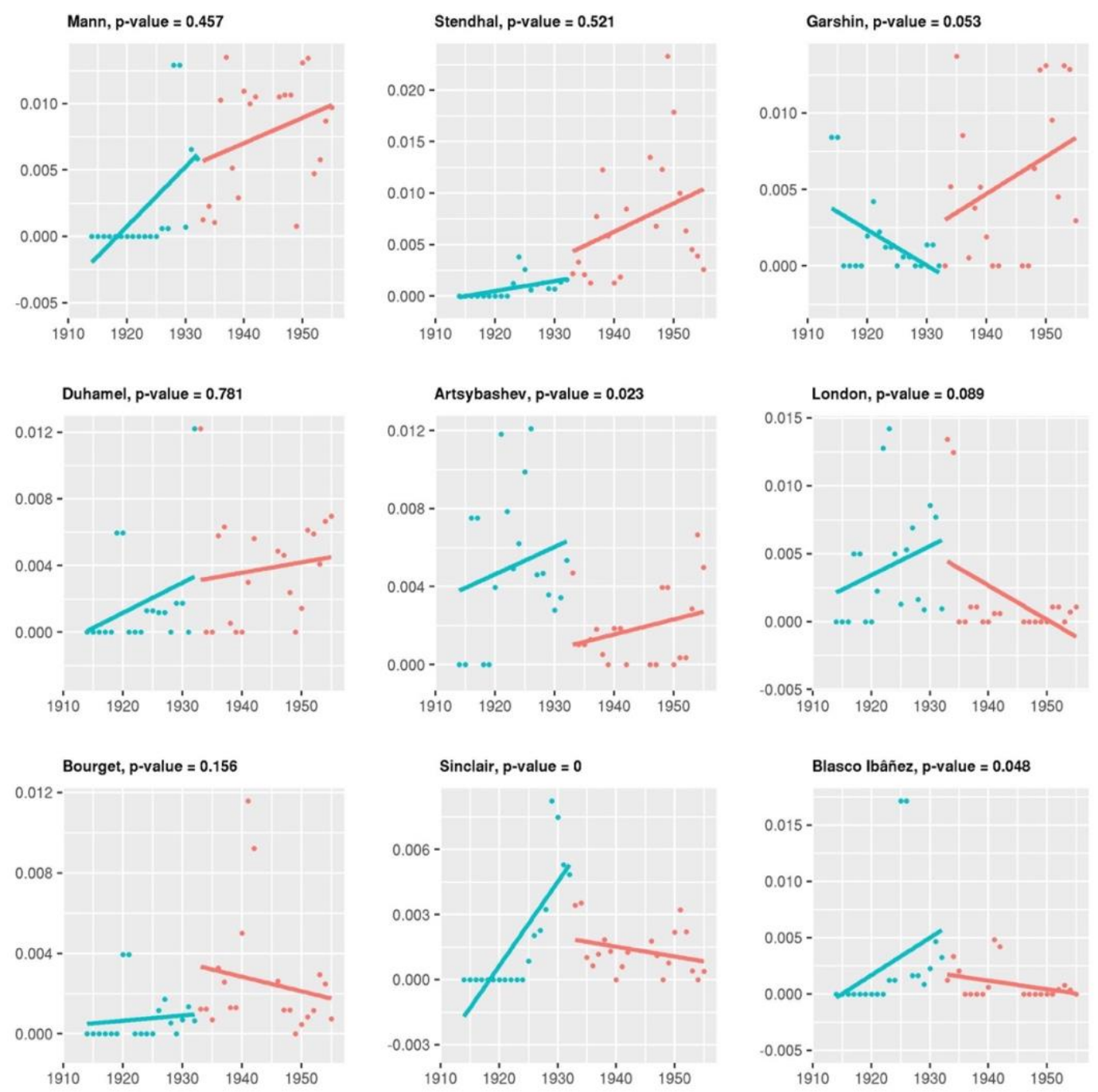

Figure 5: Chow Test plots for 9 most translated authors in Part Two, ranked right to left, top to bottom. 
Part One Authors, $p$-value $=0.794$

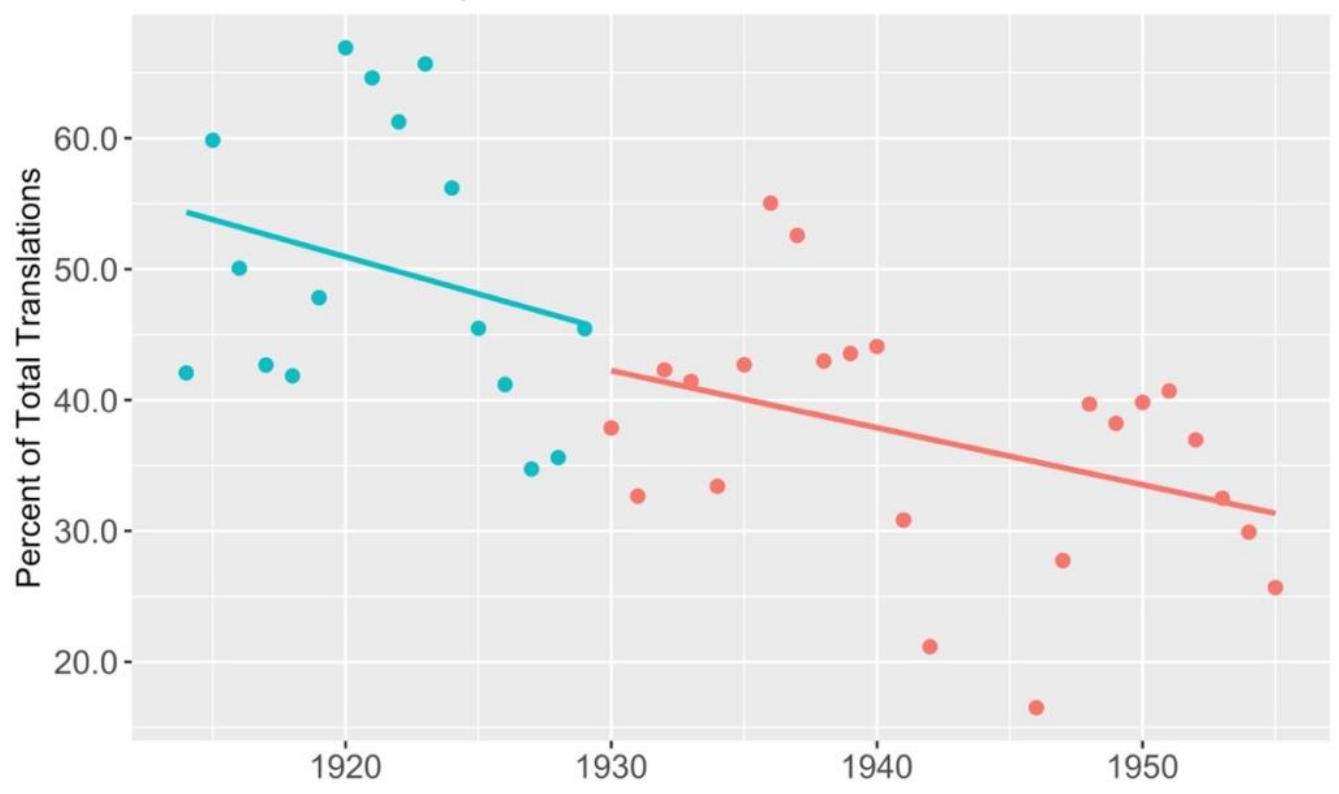

Figure 6: Chow Test plot for all authors in Part One of the anthology.

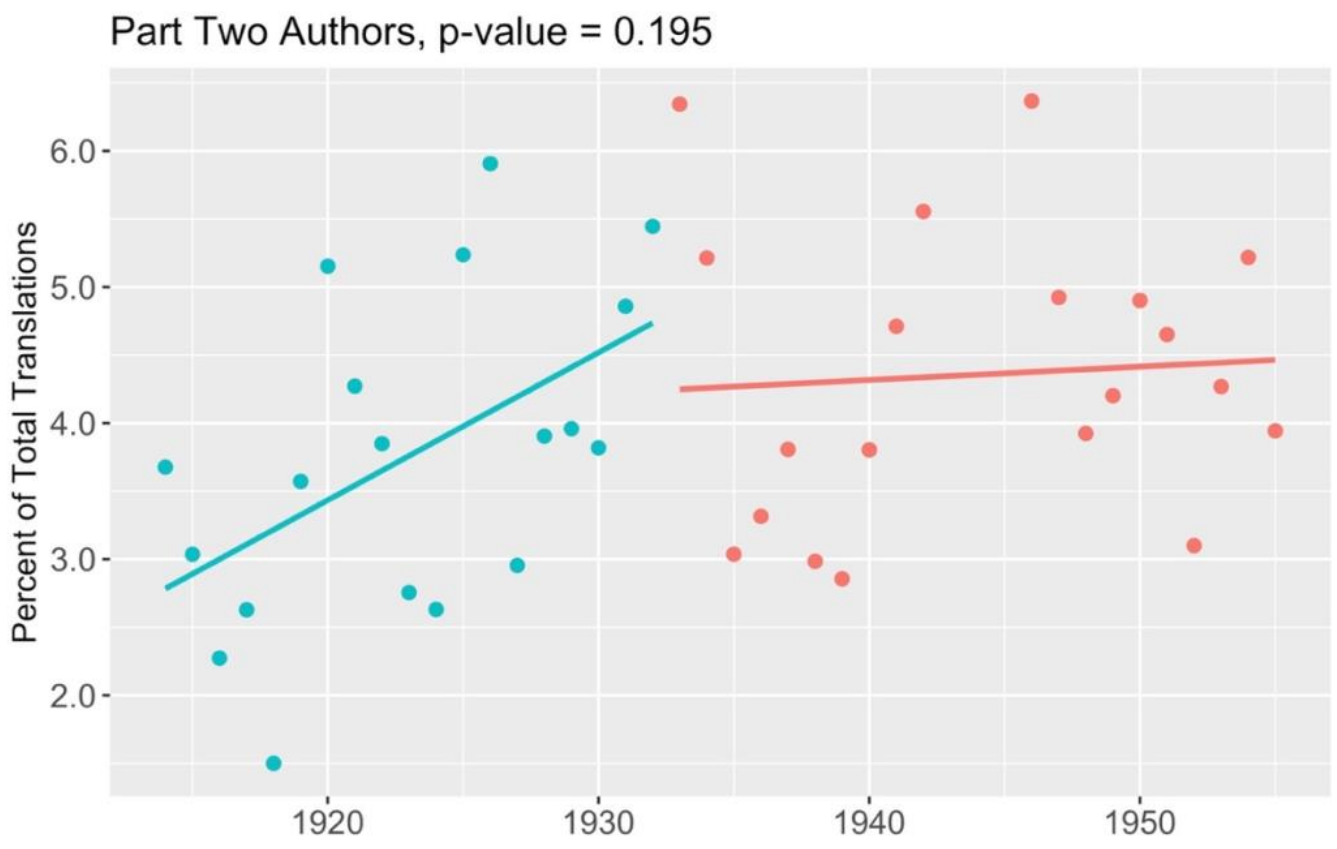

Figure 7: Chow Test plot for all authors in Part Two of the anthology. 
The aggregated trend lines push these hunches in yet other ways, adding to the evidence we already have about the divergent social function of the anthology's two parts. For Part One, there is not significant statistical evidence of a structural break $(\mathrm{p}=0.79)$ at the year 1929. Despite a lot of variation at the author level, the aggregate trend is consistently downward, suggesting that Shinchōsha bet on authors (46 in total) whose fortunes in the translation market were on the way down, though certainly not out. By 1950 , their works still make up over $25 \%$ of all translations in the dataset. With Part Two there is slightly more evidence of a break $(\mathrm{p}=.195)$ because a clear, steady ascent prior to 1932 turns into a noisy trend line showing varied levels of attention from year to year. Shinchōsha was placing bigger bets on less proven authors, which paid off for Thomas Mann and Georges Duhamel but not Jack London or Aleksandr Kuprin. Looking at the widely translated authors who were left on the table (Figure 8), these latter bets look doubly misplaced. We can imagine why Satō steered clear of Arthur Conan Doyle or Robert Louis Stevenson, not wanting to dilute the anthology's civilizing mission with the detective stories and adventure novels for which the masses truly clamored. For authors like André Gide and Herman Hesse, the lack of prior publications was perhaps reason enough to ignore them. But what of Pushkin, Ferenc Molnár (1878-1952), or Kleist (17771811), who had been, and would continue to be, of interest to publishers? Most strikingly, what of Baudelaire, for whom Akutagawa would have searched in vain for even a single line?

These questions invite further speculation about the role of the anthology in disseminating these and other foreign authors, a role that can only be fully understood upon examining the broader historical reception of each. Satō's choices were simply one act of selection (or non-selection) in a diffuse, disconnected chain, much of which is missing from the historical record. My aim is to consider how we intuit the significance of these acts outside of preconceived judgments we would otherwise bring to them, temporarily suspending these judgments with the aid of bibliographic data and a naïve Bayesian logic. Not to override them, but to begin from a different baseline for reasoning about the relative chances that a particular book or author is plucked from the swirling currents of bibliomigrancy. How this baseline can inform analysis of broader literary reception, especially as this analysis probes beneath the surface machinery of material circulation, is an open question. But at the very least it can set expectations about the likelihood of an author or work 
coming to individual or collective attention at a given time and place, allowing us to calibrate intuitions about the degree to which the fact of their being read was burdened (or not) by the weight of past choices and preferential attachment.
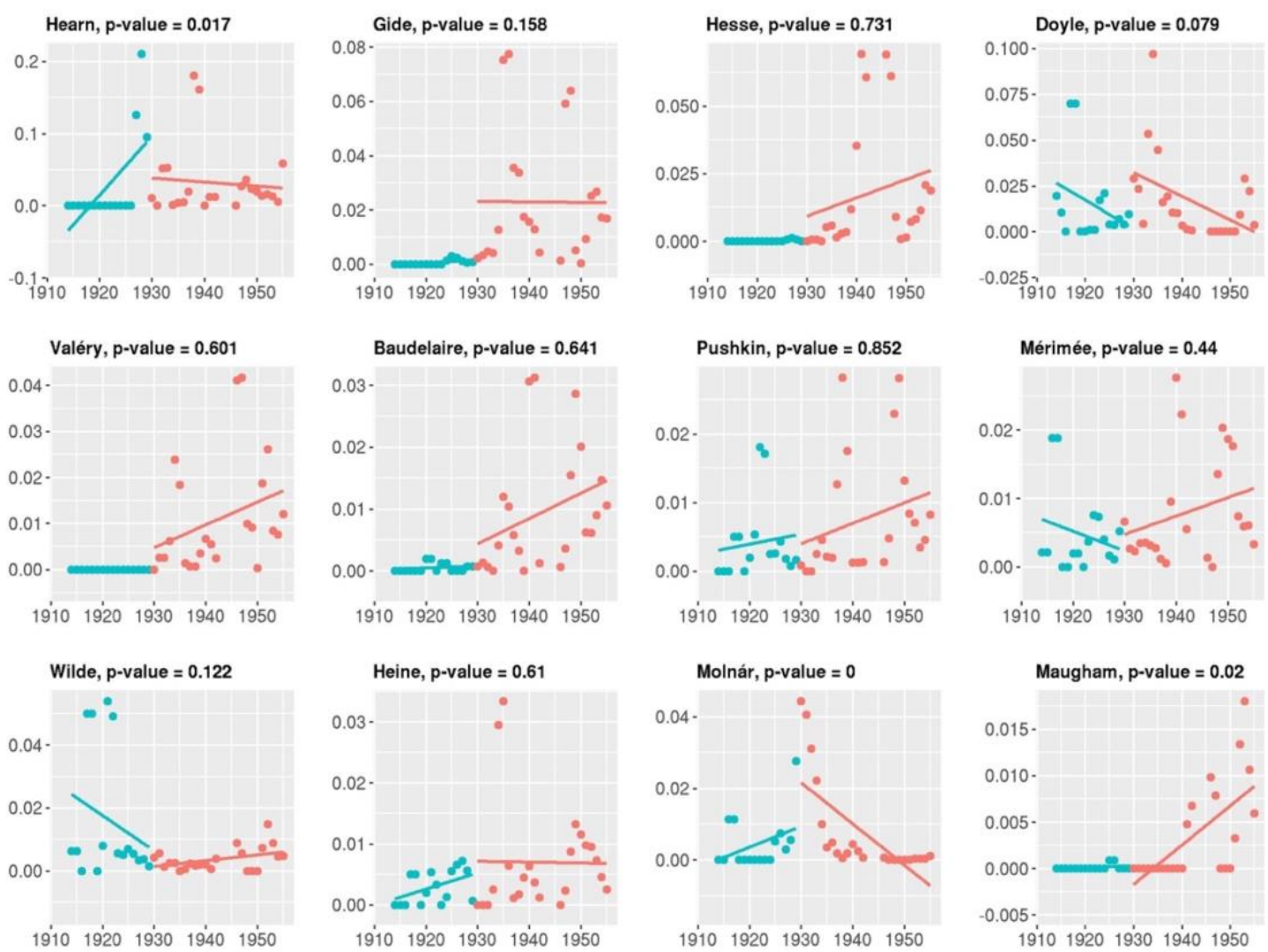

$\begin{array}{lllll}19 \dot{1} 0 & 19 \dot{2} 0 & 19 \dot{3} 0 & 19 \dot{4} 0 & 1950\end{array}$
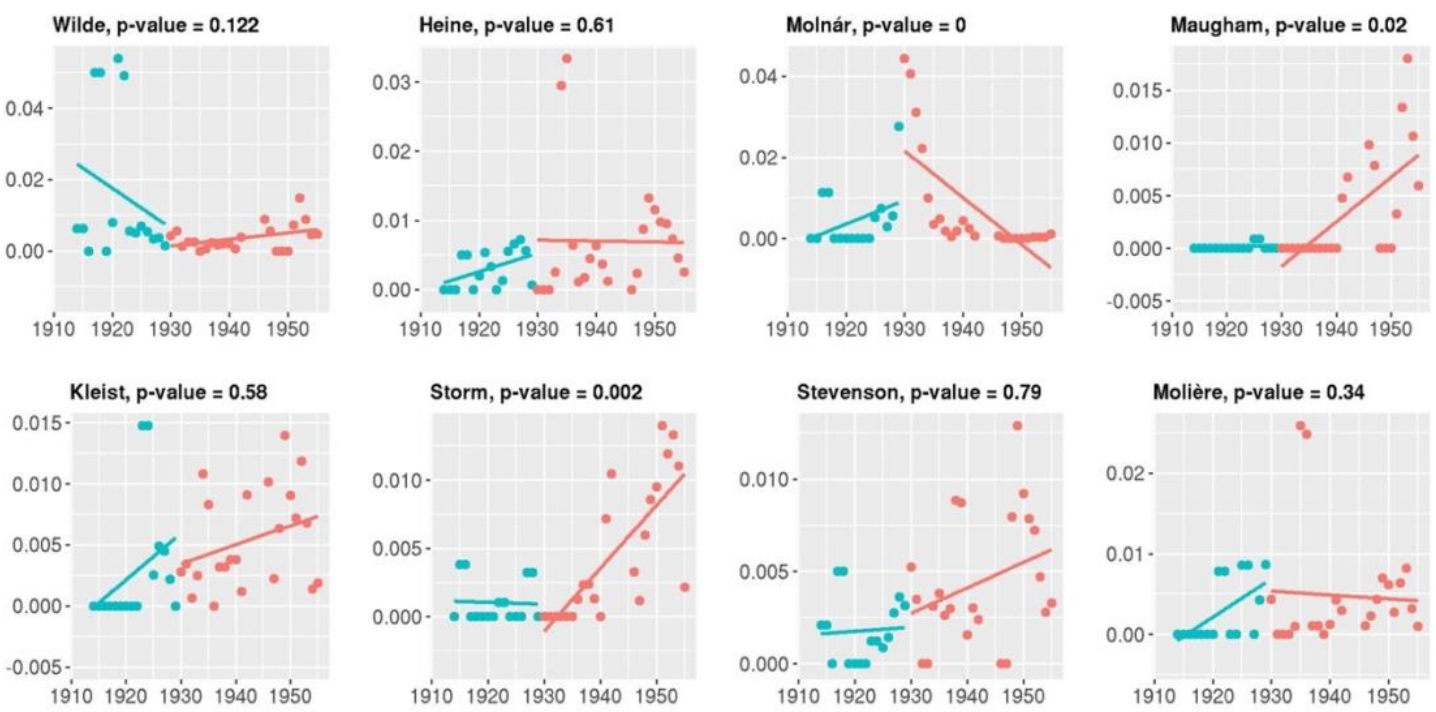

Figure 8: Chow Test plots for 16 most translated authors not included in the Shinchōsha anthology.

Such a baseline can even be comparative if other editorial or institutional choices are projected onto it. Areas of overlap and disjunction in these projections could hint at the competing intentions of publishers and other agents of bibliomigrancy by showing how they diverge from the same evidentiary baseline. Consider, for instance, a projection based on a list of recommended titles from the Association of Japanese Libraries. In 1918, the Association published a catalog for local librarians 
who were trying to stock their shelves on limited budgets and finite expertise. The subject area for Literature listed 85 volumes of translated works. Figure 9 visualizes the proportional value of all authors from 1912 to 1918, with the Association's recommended authors in blue. ${ }^{57}$

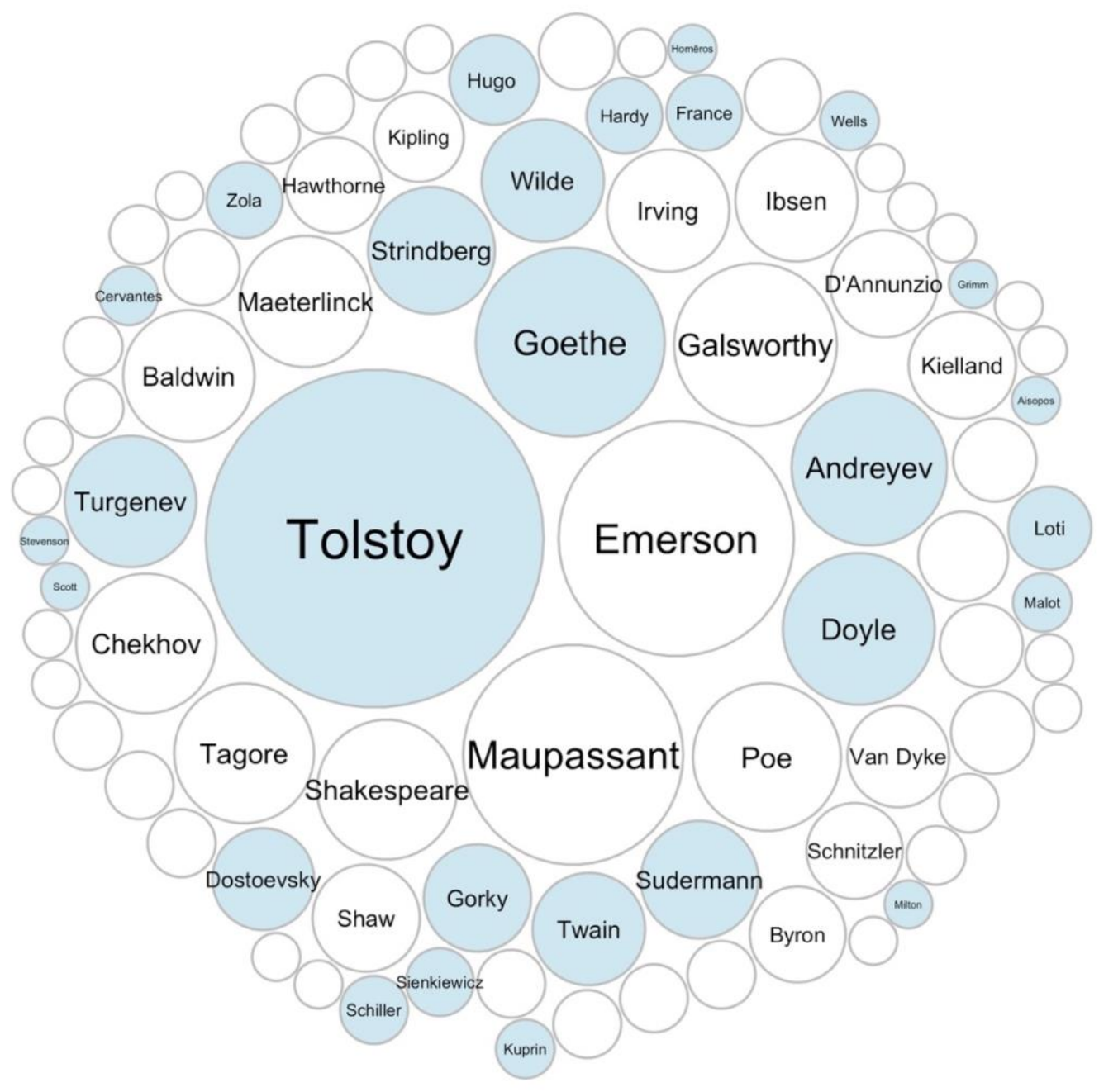

Figure 9: Proportional representation of all translated authors from 1912 to 1918. Blue circles are authors included in the Association of Japanese Libraries list of recommended works.

Right away we notice obvious commonalities and differences in the authors anthologized by Shinchōsha and those recommended for library purchase. Tolstoy and Goethe are sure bets in both cases, while Poe and Maupassant are glaringly absent from the library list. Why was the Association reluctant to include the latter? Looking at authors with few publications who were nevertheless recommended for library purchase (Jack London and Thomas More) raises questions about how their 
representativeness was rationalized in spite of little evident commercial interest. Triangulating via a common baseline is a way to ground speculation about the ideological or institutional motives of these two agents of bibliomigrancy against a shared horizon of expectation. But it also exposes the fragility of the assumption animating this Bayesian thought experiment and classical probability theory in general: that there is a true ratio to which empirical observations converge. If such a ratio existed, would six years of bibliographic data be enough to capture it? Or does it make more sense to compress the time scale to account for the cultural weight given to aesthetic innovation? No amount of longitudinal data, for instance, can predict the sudden rise of a new author or work whose value lay precisely in its rarity. What, finally, can a "true" ratio even mean when dealing with the compound results of human judgment and not the constancy of physical processes?

\section{The Laws of Frequency}

For the classical probabilists, truth ultimately lay with God. Or if not Him, then with a standard of reasonableness supposedly shared by intellectual and political elites. Probability was a measure of one's ignorance of these higher laws, whether the natural laws ordering God's creation or the moral laws of reasonable men. To update one's subjective belief through increased observation of the world was to close the gap between belief and higher laws, approximated as they were by objective frequencies. With the French Revolution and the rise of romanticism, however, this classical model came crashing down. Increased social tensions "shook the confidence of the probabilists in the existence of a single, shared standard of reasonableness," while romanticism came to identify reason itself with "unanalyzable intuitions and sensibility." By the 1830s, as historians have documented, the classical interpretation of probability seemed "both dangerously subjective and distinctly unreasonable." ${ }^{, 1}$ In its place came an alternative interpretation of probabilities as observed frequencies, effectively cutting the tie between subjective and objective probability and subordinating the former to the latter. It did not matter what beliefs one brought to the mental calculus of chance, for the truths of the world could be found directly in empirical data. Laplace, in fact, had hinted at this intellectual trajectory late in life because he "realized that where large amounts of data were concerned," the Bayesian approach and the new frequentist model produced much the same results. ${ }^{59}$ As an avalanche of numerical 
data started pouring out of state-run statistics bureaus in France and other parts of Europe, it looked to a new generation of probabilists as though observed frequencies were all that was needed to mark the limits of the humanly probable.

As Daston describes it, this transition signaled a move away from the moral sciences of the Enlightenment, which took individual psychology as its primary unit of analysis and was normative in orientation, to the social sciences of the nineteenth century, which sought to describe whole societies and understand humans at the group level. "The discoveries of the moral sciences were of what ought to be; social scientists aspired to lay bare what is." ${ }^{60}$ Early popularizers of frequentist approaches, such as Siméon Denis Poisson (1781-1840) and Adolphe Quetelet (1796-1874), conceded "that individual humans are too complex and diverse to serve as the basis of science"; the causes behind individual actions and outcomes too varied to predict. It is impossible to reason about why someone is a certain height, why they picked a certain book, or why they took their own life. En masse and over the long run, however, Quetelet and others argued that individual variance washes out to produce meaningful statistical regularities wherein can be discovered the deeper causes regulating a society. ${ }^{61}$ As Ian Hacking describes this revolution in thinking, "the mathematics of probability and the metaphysics of underlying cause were cobbled together by loose argument to bring an 'understanding' of the statistical stability of all phenomena." Even suicide, that most radical expression of free will, looked under this new paradigm as an act whose methods and seasonal timing followed constant proportions from one country to the next. ${ }^{62}$ It is hard to miss in this frequentist turn the sleight of hand that substituted one truth (e.g., divine order, enlightened rationality) for another (e.g., statistical regularity) - a "truth" just as partial and arbitrary in its construction and no less susceptible to normative claims about how people ought to be. Indeed, these ideas would form the quantitative bedrock of eugenic thought in the latter half of the century. They also invaded nearly every discipline and ushered in the reign of inferential statistics, whose tools and practices are still deeply embedded in contemporary knowledge formations. Given its pervasiveness, it is worth considering how, at the most basic level, the frequentist outlook transforms my running thought experiment.

In subordinating subjective probability to the "truths" of large numbers, our focus shifts from individual choices or events to their aggregated patterns. Under this 
paradigm, the pertinent question becomes: how are the variable choices of writers, publishers, and translators in Japan, when averaged out, distributed across the range of available foreign works? Moreover, how does this distribution compare with those of other social groupings? Probability is no longer a measure of one's ignorance of a higher metaphysical truth, but a measure of difference from some population whose statistical regularities are taken as normative, or at least indicative of an underlying stability in human action and judgment. One does not have to apply a positivist interpretation to these regularities (e.g., that they index a set of values unconsciously shared) to use them as a basis of comparison. Here I am curious whether comparison with regularities observed elsewhere reveals anything about how different or unexpected patterns of selection were in Japan. How does its bibliographic record look relative to other countries at the time? Do the collective choices about who and what to translate look divergent or "normal" when compared with those made around the world in the early twentieth century? Does Tolstoy's dominance (titles attributed to him constitute 7\% of all translations between 1912 and 1955) represent a peculiar national obsession, or does it align with contemporary trends? To reason about such questions, I juxtapose the translation data from Japan with catalog records from national libraries across the world, reconfiguring my thought experiment as a test of population differences.

The two imaginary populations in this case are publishers in Japan and publishers across the world from 1912 to 1955 . Their choices about who to publish are a loose proxy for the level of interest and attention given to specific authors by the many agents of bibliomigrancy. The question now is whether, all else being equal, there are significant differences in the choices made by publishers in Japan and those made elsewhere. Did they choose Tolstoy, for example, over other foreign authors at a rate significantly different than the rate he was selected by publishers outside Japan? Would knowing this alter how we reason about the relative unexpectedness of Tolstoy's, or any other author's, reception in Japan? To answer this means obtaining a picture, however approximate, of who publishers around the world were choosing. At the very least we need a sizable random sample of all the translations published in other countries during the years of interest. Here I rely on a database created with Virtual International Authority Files (VIAF), which group together name authority files from 41 national libraries as well as from country-wide union catalogues and other institutions and specialized databases. This includes many of the national 
libraries in Europe, North and South America, the National Library of Russia, and several libraries in the Middle East and East Asia. ${ }^{63}$ These VIAF files act as unique identifiers for authors, combining information about an author's preferred and alternate name forms with the original and translated works associated with these names. Using these files, one can create a subset of authority files for just works, aggregating data on the appearance of a single work across multiple languages to generate a list of translations held in contributing libraries. Filtering down to translations published between 1912 and 1955 (roughly 72,500) and grouping them by author (over 32,000 in total) provides a global snapshot of the world literary market roughly comparable to what we have for Japan.

To be sure, it is a distorted picture for reasons related to VIAF itself and the historical structure of the global language economy. For one, the creation of VIAF files requires coordination across different institutions, languages, cataloging systems, and metadata schemas, leaving much room for error. According to an analysis by Matt Erlin and Doug Knox, the files are heavily skewed toward the contemporary period (post 1990); likely contain errors with respect to dates of first publication; and sometimes fail to assign standard ISO three-letter codes to the language of translation, making these files harder to include in analysis. ${ }^{64}$ For these and other reasons, the global snapshot certainly undercounts the real number of translated works. This does not necessarily make it a poor sample, however, unless the errors lead to systematic biases. However, biases can also be introduced by historical and material factors. In places where bilingualism or multi-lingualism predominate, or where an audience exists for reading works in the original (French language literature being an obvious case), certain authors may go untranslated and thus their overall significance in the world market will be downplayed by a focus on translations alone. Another potential bias stems from the use of individual volumes as the unit of record. This privileges longer-form fiction published as single books and means that writers who stuck to shorter forms are likely underrepresented, particularly if their stories were often published as part of multi-author anthologies or collections. The VIAF dataset ultimately provides but one picture of the world trade in literature in the early twentieth century and will need to be supplemented with others. Provisional as it is, its value comes from being an aggregate sample across so many languages and national archives. It is worth imagining how even 
such a partial picture can shift expectations for how far patterns of literary attention in Japan deviated from this projected norm.

To do this requires some manipulation of the two datasets so that they are roughly comparable. For the Japan data, this means first eliminating reprints of translated works, which are not accounted for in the VIAF data. Filtering on unique authortranslator combinations leaves a total of 23,030 entries. ${ }^{65}$ This does not get around the problem that the Japan data is more granular than the VIAF data because it counts individual titles in collections and anthologies, not just discrete volumes. A more commensurable dataset could perhaps be constructed from records in Japan's National Diet Library by searching for volumes attributed to all 2,400 unique authors in the Japan translation data. For my purposes here, I stick with the original dataset, but further work is needed to gauge how different the relative proportions of translated works are from those generated by a volume-based count. ${ }^{66}$ For the VIAF data, which also includes non-fiction, I adjust the total count of translations so that it more closely reflects only the number of literary translations in the dataset. After this adjustment the number of entries drops to $62,786 .{ }^{67}$ The final step is to compare the proportions of entries by each author relative to these totals using a two-sample proportion test. This statistical test compares two populations (e.g., publishers in Japan and publishers around the world) to see if they differ significantly on a single trait (e.g., preference for Tolstoy), the null hypothesis being that there is no difference. The higher the difference in proportions, the more evidence there is to reject the null hypothesis within some confidence interval.

Taking Tolstoy as an example, his 1,633 entries compose roughly $7.1 \%$ of the Japan data. In contrast, his mere 90 entries in the VIAF dataset represent about .14\% of the total. A two-sample proportion test confirms that the difference of $6.95 \%$ is highly significant $(\mathrm{p}=0)$, with a confidence interval of \pm 2.34 . That is, if these proportions adequately reflect the degree to which publishers in Japan versus publishers elsewhere preferred Tolstoy, then we can easily reject the hypothesis that their level of attention to him between 1912 and 1955 was similar. The confidence with which we can reject the null hypothesis is bound to waver with the underlying data used, but as we are interested in the relative difference in proportions and not absolute counts, it will be less sensitive to minor fluctuations. Still, the question remains of what this confidence gets us. Tolstoy's extraordinary popularity in Japan has long 
been noted by scholars, in part owing to earlier work on some of the same bibliographic data used in this essay. In 1981, a group of historians interested in Russo-Japanese inter-cultural relations counted the number of translated volumes for the top 32 most translated authors and ranked them accordingly (Table 2). ${ }^{68}$ Tolstoy's dominance on this list has since sparked several in-depth studies seeking to explain his cultural and intellectual force in Japan and later Korea, where writers adopted the same predilection for Tolstoy and Russian literature in constituting their own national literature. ${ }^{69}$ But if the Japan data already suggested how normative was his influence there, only by comparing it against the VIAF data can we see how abnormal this persistent influence was compared with other parts of the world. His dominant presence in one materialization of world literature looks less predictable when viewed through the lens of another.

\begin{tabular}{|l|l|}
\hline Author & Number of Works \\
\hline Tolstoy & 2,608 \\
\hline Maupassant & 1,753 \\
\hline Lafcadio Hearn & 1,128 \\
\hline Chekov & 1,110 \\
\hline Goethe & 859 \\
\hline Dostoyevsky & 757 \\
\hline Poe & 522 \\
\hline Gide & 519 \\
\hline Gorky & 495 \\
\hline Hesse & 415 \\
\hline Turgenev & 402 \\
\hline Doyle & 364 \\
\hline Valéry & 359 \\
\hline Balzac & 324 \\
\hline France & 311 \\
\hline Schnitzler & 265 \\
\hline Rolland & 260 \\
\hline Strindberg & 236 \\
\hline Baudelaire & 230 \\
\hline Thomas Mann & 220 \\
\hline Pushkin & 210 \\
\hline Mérimée & 204 \\
\hline Gogol & 200 \\
\hline & \\
\hline
\end{tabular}




\begin{tabular}{|l|l|}
\hline Wilde & 192 \\
\hline Stendhal & 182 \\
\hline Philippe & 181 \\
\hline Maugham & 180 \\
\hline Shakespeare & 179 \\
\hline Heine & 176 \\
\hline Molnar & 166 \\
\hline Maeterlinck & 154 \\
\hline Garshin & 139 \\
\hline
\end{tabular}

Table 2: Top translated authors into Japanese, 1868-1955.

Repeating this analysis for the most translated authors in Japan reveals that the disproportionate interest given to Tolstoy in this period was among the highest of any author. Figure 10 displays the 30 authors with the greatest proportional difference from the VIAF data. Tolstoy is fourth from the top. Looking down the list, we are confronted with yet another arrangement of familiar names, although now selected and sorted according to a frequentist logic and informed by the compound choices of translators, publishers, and libraries across a forty-year span and across dozens of countries. At this scale, the path of world literature in Japan has been narrowed to a seemingly random assortment of Russian (Vsevolod Garshin, Tolstoy, Chekhov), French (Valéry, Maupassant, Prosper Mérimée), American (Hearn, Emerson, Poe), and German (Theodor Storm, E.T.A. Hoffman, Hesse, Kleist, Goethe) writers who Japanese agents of bibliomigrancy revisited and revalued more often than their counterparts elsewhere. Here, however, the randomness is bounded by baseline evidence about who was being widely translated and circulated outside of Japan. Where the shelves of Maruzen and the editorial decisions at Shinchōsha had provided an opportunity to gauge the likelihood of individual choices against base rates of translation in Japan, the VIAF data provides a way to gauge the likelihood of collective decisions in Japan against those elsewhere. This is an image of world literature defined by who was being translated domestically, but also by who was being translated in inordinate amount relative to other places. 


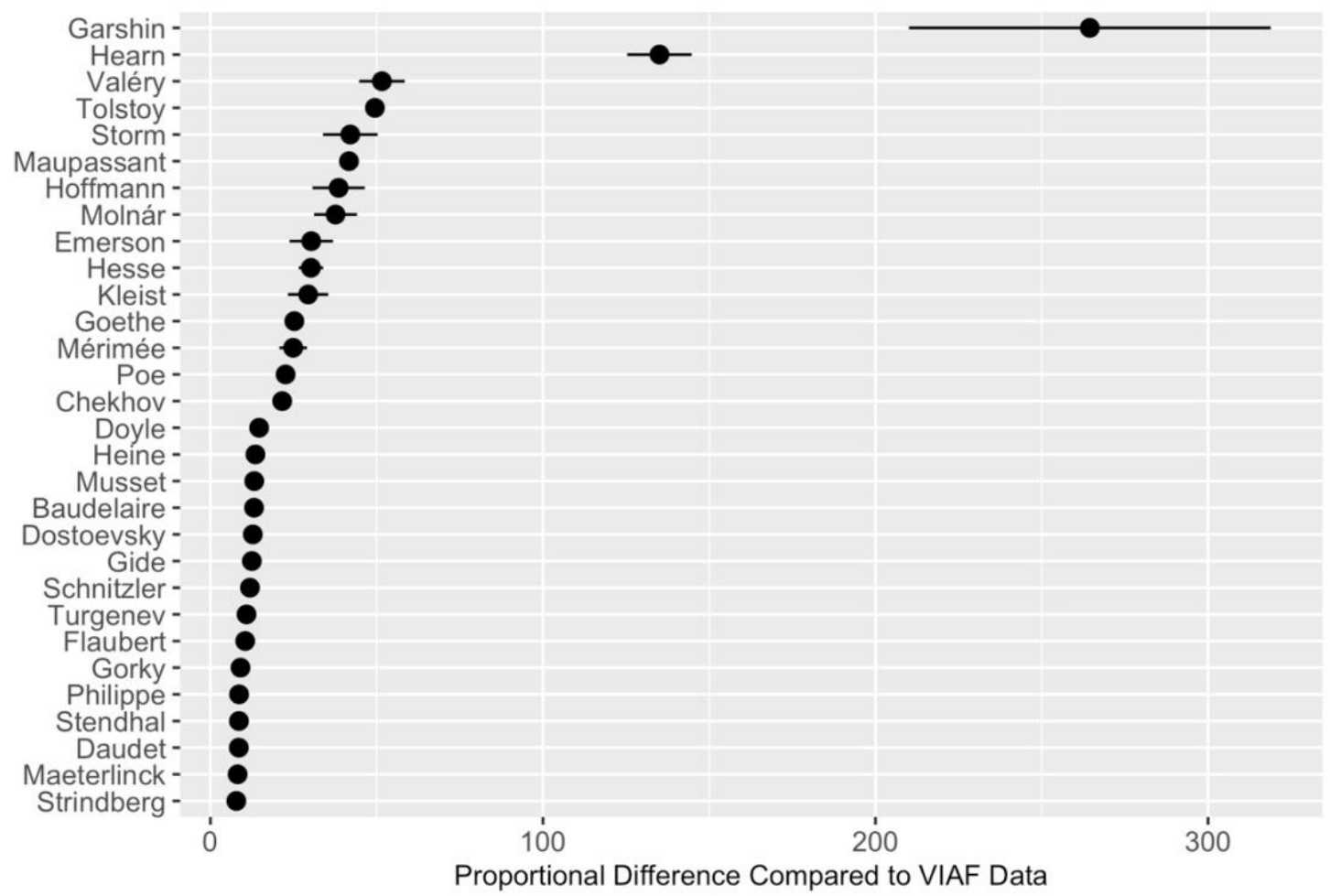

Figure 10: The 30 authors with the greatest proportional difference from the VIAF data. For reference, the difference for Garshin is $264 \%$ and for Strindberg 7.8\%. All differences are statistically significant.

What, now, to do with this image? Should it change our certainty about the chances of these authors being translated and read in Japan? The previous thought experiment told us that the chances of Tolstoy or Maupassant being plucked from the swirling currents of bibliomigrancy was already high by the late 1920s. These results are further evidence of how predictable such choices were for Japanese consumers of translated literature. Asked to wager on the likelihood of any writer pulling Tolstoy from the shelves of Maruzen or from personal memory, knowing that this writer lived in prewar Japan, we might be willing to bet more money on him than other authors. But would we be as confident about Mérimée (1803-1870), the French Romanticist best known for Carmen; Theodor Storm (1817-1888), a central figure in German literary realism; or the Russian Garshin (1855-1888), who tops the list but is probably the most obscure of any author in Figure 10?

The response to this question will depend, first of all, on how willing one is to treat the VIAF baseline as an adequate approximation of global patterns in translation. It will also depend on how one figures the act of selection and at what scope. The more one insists on contextualizing the act as contingent on a particular writer acting at a 
particular place and time, the easier it will be to reject this coarse baseline for the elegance and mystery of caprice, which can seem the more rational explanation once one starts enumerating all the many variables that potentially impinge on a single decision or outcome. ${ }^{70}$ But it is worth noting that this process of enumeration will itself depend on whatever subjective beliefs and predispositions one brings to the betting table. Indeed, cognitive psychologists have argued that such beliefs typically override the most basic principles of probabilistic reasoning and statistical inference. If I hesitate to wager much on Garshin, whose influence on Japanese letters feels improbable to me even as the data tells me to believe otherwise, perhaps this says just as much about me as it does about the data.

\section{Seeing is Believing}

The notion that one's degree of certainty in a given outcome corresponds to the amount one is willing to wager on it is an old idea in probability theory. In the case of Garshin, my sense of his improbability, based on my ignorance of him prior to this study, corresponds to a reluctance to bet much at all. A scholar better versed in Russo-Japanese literary relations might wager more, although in truth Garshin has received scant mention in scholarship to date. We can debate whether such wagers are a reasonable proxy for subjective probabilities, but mine would undoubtedly diverge from others based on prior knowledge and experience. Indeed, these differences, as we know, are what a Bayesian framework tries to account for by directly incorporating subjective probabilities into its calculus. Yet it also ties them to observed frequencies such that they are updated when one obtains new empirical evidence. ${ }^{71}$ Allowed to run its course, this idealized, rational calculus will produce probabilities with little relation to the wagers we make on the spot with only individual experience to guide us. But how are they different, exactly? What is the mind doing instead when making predictions under uncertainty? How far does it stray from the codified rules of probability theory?

In the 1960s and 70s, an entire sub-field of cognitive psychology emerged to tackle such questions. As the Bayesian framework experienced a resurgence after over a century of Frequentist hegemony, new research programs grew up around a theory of the reasoning mind as Bayesian statistician. ${ }^{72}$ Some of the most influential experiments designed to test this theory were carried out by Amos Tversky and 
Daniel Kahneman, who aimed to show that the human mind, when making judgments or predictions under uncertainty, relied on a small number of "heuristic principles" that reduced "the complex tasks of assessing probabilities and predicting values to simpler judgmental operations." These were in general quite useful but could "sometimes lead to severe and systematic errors."73 Particularly egregious were errors caused by "base-rate neglect," which was understood as the tendency to ignore prior probabilities (base rates) for other kinds of diagnostic information. Tversky and Kahneman consistently found that when test subjects were presented with "real-world" problems and asked to give the probability of a particular outcome, their predictions were typically guided by irrelevant heuristics or circumstantial evidence rather than by a consideration of base rates. For the statistician, such neglect was tantamount to ignoring the most solid piece of information one had for calculating the probability of an event.

Tversky and Kahneman were interested in how the mind made predictions about the world that flew in the face of basic statistical rules, at least as these had come to be institutionalized by the 1970s (e.g., the effect of sample size on sampling variability; a regression to the mean). They enumerated several heuristic principles that subjects relied on when presented with a real-world probability problem, each generating its own kind of systematic error. The first was representativeness, which was the tendency of subjects to disregard prior probabilities (base rates) and expected predictive accuracy when they were given individuating information or "diagnostic" information. For example, when asked to predict the likely profession of a person (e.g., lawyer or engineer), and provided a brief description of their character traits or habits, subjects made predictions based on how well the description conformed to common stereotypes of lawyers or engineers, not on the given base rates of each profession within the population. ${ }^{74}$ A second heuristic that Tversky and Kahneman identified was availability, which was the tendency to assess "the frequency of a class or the probability of an event by the ease with which instances or occurrences can be brought to mind." This ease of bringing to mind was prone to many kinds of bias, all of which contributed to the over or underestimation of probability: bias due to the retrievability of an instance (e.g., lists of names with more famous people were given more predictive weight); to the salience of an instance (e.g., how recently had one seen a car crash); to the effectiveness of a search set (e.g., abstract words were judged to be more frequent than concrete words given their higher availability of 
contexts); or to the imaginability of an instance (e.g., the risks of an expedition will be overestimated the easier it is to construct possible contingencies, and vice versa). Finally, a third heuristic was adjustment and anchoring, which refers to the tendency of subjects to overestimate the probability of conjunctive events (i.e., a series of events that occur in succession) and to underestimate the probability of disjunctive events (i.e., complex sequences of events where failure of one event to occur can lead to overall failure) ${ }^{75}$

Research into human judgment under uncertainty has progressed well beyond the preliminary findings of Tversky and Kahneman, becoming only more relevant in an age of data-driven journalism and disinformation warfare. But this early work is still worth highlighting for the ways it puts rational probability theory and subjective probability into dialogue. One lesson to take from it is not that we should reason more like the idealized statistician, but that there is value in being self-aware about the particular ways the mind deviates from what this ideal reasoning would predict. ${ }^{76}$ How might an awareness of our heuristic principles, whether as effect of cognitive tendencies or disciplinary habits, help literary historians recalibrate their encounters with empirical data? When we celebrate the unexpected readings generated by these principles, enacting our own version of base-rate neglect, what biased judgments do we wind up privileging instead?

The juxtaposition of a notional ground truth against individual bias recalls Barbara Herrnstein-Smith's appeal to "personal economy" as that which invalidates any attempt to objectively predict the value of a work. If readers invariably price artistic objects "in relation to the total economy of [their] personal universe," then all we have is personal bias to guide value judgments. ${ }^{77}$ John Guillory took issue with Smith on this point in Cultural Capital, insisting that her philosophical critique ignored the actual circulation of values. "It is only in the graduate seminars that one can have the thrill of experiencing the 'contingency' of value, a thrill which is produced by the very connotations of the word 'contingency,' its broad hint that values are merely arbitrary, that they have no ultimate determination beyond chance and circumstance. Any analysis of objective social relations will on the contrary reveal that both 'values' and the discourse of value are historically determined as objective social facts." 78 Contorting our ears a bit, it almost sounds as though Guillory is warning against the dangers of base-rate neglect. 
His warning, however, sticks to the language of economics, critiquing Smith for neglecting the fundamental imbrication of use value with exchange value. Specifically, he argues that "uses" (e.g., of a book by a reader) "are not simply chosen from amongst a potentially infinite number of equal possibilities (aesthetic, political, moral, hedonic) but are complexly articulated in nested hierarchies according to the relation between the specific domains of the social named by such categories as the aesthetic, the political, the moral, the hedonic."79 To suggest, as Smith does, that the contingency of such uses relies on the "scrappiness" of human behavior, making them irreducible to any single measure of value, is to suggest that this contingency exists wholly prior to experience. Guillory, in opposition, insists that it is "certain social relations that select certain contingencies as consequential." 80 To ignore these relations is to misunderstand individual choice or need as somehow free of external constraints, when in fact one's personal economy is already prefigured by political economy (i.e., the commodification of works of art as objects of exchange and (in)utility). However irreducible or unexpected the "uses" of a work might seem at the level of individual readers, they are delimited in advance by social relations encoded in a work's "exchange" value, whose criterion decidedly does not resist any single calculus: "its measure is money." 81 To the extent Guillory sees exchange value as a check on the range of likely use values, there is a conceptual analogue in the idea that base rates, among other statistical rationalizations, are a counterweight to the heuristic principles that the mind gravitates to under uncertainty. To neglect either is to let human scrappiness extend the range of the probable in ways that a deliberate accounting of the socially and historically possible will not always warrant.

To be clear, my aim is not to force a choice between use value and exchange value, or subjective probabilities and objective statistical baselines, but to attend to the dialectic tension that obtains between them when historicizing textual encounters. Treating the results about which authors were translated into Japanese in greater proportions relative to other parts of the world as a kind of base rate - a kind of proxy for the accumulated exchange value of foreign authors in Japan-how does an awareness of this rate interact with initial judgments about a given author's relative importance, or with what we predict to be the likely judgments of others? Returning 
to Garshin, how does awareness of his apparent overvaluation in Japan's literary translation market color our reading of past encounters with his fiction? Consider a short essay from 1940 titled “Garshin's 'The Red Flower' and Myself," published in an obscure medical journal by one Yamanoi Aitarō. It opens with Yamanoi's personal reminisces of how he inexplicably came to be fascinated by this story, one born of Garshin's own experiences at the Saburova Dacha asylum, "in particular its depiction of the life and emotions of a patient gone mad." Yamanoi tells us that he first encountered the story in its original Russian around 1917 at the Nikolai Cathedral in Tokyo, the seat of the Japanese Orthodox Church since 1891 and a major conduit for the diffusion of Russian literature and thought into intellectual circles. At the time he was taking Russian language classes there and availed himself of the library reading room with its large collection of "rather outdated authors": Kuprin, Goncharov, Chirikov, Chekov, Gogol, Potapenko, Garshin, and Korolenko. ${ }^{82}$

Yet aside from Gogol and Goncharov, these authors were not as "outdated" as the major novelists who, even by this time, continued to hold sway over the translation market, in particular Tolstoy, Turgenev, and Dostoyevsky. Garshin, together with Chekov and Vladimir Korolenko, belonged to the 1880s generation of new writers that followed in the shadow of these luminaries. The decade has been characterized as 'an anti-climactic time of 'revolutionary pessimism,' with routed revolutionaries licking their wounds and the population cowed and silenced by official repression." While an oversimplification, as Russian literary historian Peter Henry notes, there was a real sense among writers of an increasingly oppressive political situation, to which some responded by rejecting the realist mode of their predecessors to experiment with newer narrative forms and styles. Garshin "epitomizes the move away from the broad canvas and the solid objectivity of the realist novel towards an introspective and microscopic, often fragmentary, literary form, reflecting perhaps the uncertainties and self-doubt of his times." 83 This move entailed, among other things, an attention to the transcendental and hyper-real, a reliance on allegory and symbolist imagery, and an interest in defending society's underdogs, whether infantrymen on the front lines of war (e.g., "Four Days"), railway linemen serving the desolate expanses of empire (e.g., "The Signal"), or patients suffering in insane asylums (e.g., "The Red Flower"). The last of these, written in 1883, refashions Garshin's personal experiences into an intimate and detailed account of manic 
schizophrenia that shuttles between an intense focalization of unfolding inner madness - the patient is increasingly convinced that a red poppy in the hospital grounds harbors a Cosmic Evil - and a more neutral, "normative" perspective that, embodied by the patient's doctors, observes this growing obsession from the outside. This shuttling sets up a tension between the normal world and its human agents on the one hand, who are "content with surface realities...concerned with what is known or knowable and consistent with a meaningful scheme." And on the other, the abnormal experience of the patient, which is "shown as infinitely richer, transcending the limitations of reason, space and time" by collapsing multiple times and identities, however paradoxically or illogically, into objects like the poppy or the hospital, and which ultimately serves as the basis for "an alternative truth." ${ }^{44}$

Of the roughly two dozen short stories Garshin wrote in his lifetime, "The Red Flower" was a favorite of his contemporaries and particularly well-liked by his adoring fans. In 1886, for instance, a public reading of the work provoked mass hysteria. By one account, after twenty minutes of unruly ovation, Garshin had only to pronounce the two words of the title before "the theatre was again seized with an outburst of seemingly interminable applause." ${ }^{85}$ Henry declares that Garshin was "one of the most widely-read writers of his generation," a popularity partly sustained by his association with mental illness. When "an invisible, all-powerful force" sent Garshin tumbling from a third-floor stairwell in 1888 and to his death a few days later, this association became a fixture of his posthumous reception. ${ }^{86}$ The literary aesthetics of the 1880s combined with popular theories of mental illness to produce "a uniquely pre-decadent illness image" of Garshin that made him "an imagined source of mass psychogenic contagion" while alive and, after death, preserved a public memory of him as a saintly, "sublime nervous degenerate." 87 A half-century on and a continent away, Yamanoi would perform his own pathological reading of Garshin and "The Red Flower," a story he couldn't seem to get out of his head. A few years after discovering it at the Nikolai Cathedral, during a visit to a museum in Port Arthur commemorating the Russo-Japanese War (1904-05), he wondered if the Russian-made straightjackets exhibited there were identical to those worn by Garshin at Saburova Dacha. Later, he was tortured by the story's hallucinatory visions as he himself was admitted to a mental hospital for several years. In 1937, recovering from a long bout with mental illness, he found the story again in Japanese translation. Despite feeling no emotional response this time, it remained for him a 
"fateful book." It seemed as if the image of the red poppy might "race round behind his eyelids endlessly, for as long as he lived." 88

This arc of reception from Garshin to Yamanoi seems almost too perfect. As if the thousands of pathways Yamanoi could have cut through the swirling currents of bibliomigrancy were swept aside for the only path ever possible. Contingency begins to look like necessity, but also fate. This is partly due to the way he tallies up a series of coincidences such that "The Red Flower," in conspiratorial fashion, becomes a cipher for his own biography. In pairing these coincidences with my own selective summary of the archive, I further strengthen a sense of inevitability. At the level of individual reader response (i.e., use value), where it is often hard to see beyond the sparse details left to us by historical actors, this may be a satisfying outcome. If all responses are equally probable, because equally unexpected, then any response gleaned from the archive can begin to feel like the only one possible. But at the level of Yamanoi's material encounter with Garshin (i.e., exchange value), should we let these same sparse details guide our judgment? Or does individuating information of this sort, to use Tversky and Kahneman's words, prime us to double down on one conclusion at the risk of neglecting other relevant information (e.g., base rates)? Put otherwise, how might attention to this extrinsic information shift our own mental calculus about, for instance, the chances of a reader in Japan finding "The Red Flower" in its original Russian in 1917? Or of rediscovering it in translation in the 1930s? Or, for that matter, of reading it pathologically? How does our perception of these individual acts of selection change with evidence about the accumulated selections made before them?

It may seem we have ended back up at Mani's initial injunction to consider how the material specificity of circulation shapes encounters with world literature as object and idea. Aren't these just the concerns of good old-fashioned book history? Perhaps. But within the terms of this final thought experiment, our predictions about the chances of a particular book being read at a particular time are no longer framed as a choice between fate and chance, statistical determinism and pure randomness, but instead as a continual negotiation between competing heuristics. At one end are the habits of mind that lead us to privilege or overweight information in ways that run counter to the established rules of probability theory. At the other are these very same rules proposing a different formula for balancing subjective certainties with the patterns found in bodies of collective evidence. The latter are not useful because 
they provide a form of absolute objectivity against which subjective ignorance is laid bare, as if these larger bodies of evidence were not themselves partial and shot through with the biases of the actors and institutions that created them. Indeed, the false objectivity of a concept like "base rate" is apparent as soon as we start asking what that rate should be for 1917, or the 1930s, or the propensity to read Garshin pathologically. ${ }^{89}$ The goal is not to eliminate the gap between competing heuristics, but rather to entertain the thought that our judgments under uncertainty are enriched when we consciously allow these heuristics to push and pull on one another.

Thus far, my own judgments about Garshin's likelihood of being read in Japan have oscillated between the minor particulars of a single reader and the broad patterns to be found in publishing records and library collection practices spanning more than four decades. If the latter is what brought attention to Garshin's exceptional reception in Japan during this period, it explains little of how such an accumulation of value came to pass by 1940 . For this we need to narrow the range of oscillation and consider how the particulars in Yamanoi's account might be paired with more meaningful base rates. For instance, in the case of his discovery of Garshin in 1917, a suitable base rate might attempt to capture the author's overall popularity in Russia or in the global market for foreign translations. Henry suggests that Garshin was "one of the most widely-read writers of his generation," a popularity sustained by fans and critics well into the pre-revolutionary and Soviet periods.$^{90}$ His stories also found a wide audience in Europe and America. "By the turn of the century there were translations in other Slavonic languages (Czech, Polish, Bulgarian, SerboCroat), Yiddish, French-Maupassant prefaced one such volume with an essayEnglish, Dutch, Swedish, Danish, Spanish, Italian and Greek." ${ }^{.11}$ French may have been the primary coin of the world Republic of letters in this period, but English was an equally, and in some cases more, valuable currency for Russian fiction after 1885. Garshin's stories began to appear in British periodicals and short story collections from the 1880s and 1890s, riding a "torrent" of translations unleashed at this time and culminating in the "Russian craze" of 1910 to $1925 .{ }^{92}$ While this craze did not garner him the degree of attention given to his more illustrious predecessors, it did result in a standalone volume of seventeen stories published by Duckworth of London in 1912 and included in its Reader's Library series, a hodgepodge of "books of individual merit and permanent value" by British, American, Russian, and French authors. ${ }^{93}$ This became the source for the first Japanese collection of Garshin's 
stories, including "The Red Flower," translated by Tanizaki Seiji in 1914 as part of an early venture in the fledgling market for foreign literature anthologies. ${ }^{94}$

While such details, based on select bibliographic evidence, do not provide a robust base rate, they can revise our initial judgments about the probability of Garshin's works being found at the Nikolai Cathedral in 1917. For one, they show us the barest outline of a sequence of contingencies, both foreign and homegrown, that arguably add up to a higher chance of these works arriving in Japan. But they also raise questions about how Garshin's local availability was sustained even as his fortunes in the world literary market tailed off, at least according to the VIAF data. His absence there may be an effect of how his works generally circulated, which was more often through literary compilations than standalone volumes. Even acknowledging the possibility of his being undercounted in the VIAF data, his overvaluation in Japan is precisely because of the repeat publication of standalone volumes. By the time Yamanoi rediscovered Garshin in translation, no fewer than three standalone publications had appeared since the 1914 volume, each by a different translator. This included a three-volume set of collected works published in the early 1930s as part of a "World Masterpieces" series and the 1937 volume that fell into his hands - a collection of five stories, including "The Red Flower," published as an Iwanami Bunko pocket paperback. ${ }^{95}$ Individual stories had also found their way into a literature primer for high-school students (1925), an anthology of foreign short-fiction (1925), and even volume 24 of the Shinchōsha anthology (1929). ${ }^{96}$ Still, between 1912 and 1937, Garshin was only the 55 ${ }^{\text {th }}$ most translated author according to the National Diet Library data.

To be clear, exploring the space of possible base rates is not about coming up with a precise probability estimate. There are far too many variables in play at the level of the single event and too many unknowns. Base rates are simply a lower bound against which to evaluate the ceilings of our evolving hunches and presuppositions. Garshin's lower rank in 1937 (he would climb to 34 by 1955) may pull those ceilings down on first glance, but we can push them up again by weighing evidence that accounts for his relative value in other ways. Material factors, for instance, like the fact that he circulated in pocket paperback form, or certain kinds of paratextual evidence. Here too the idea of base rate can be loosely applied if we set Yamanoi's pathological reading against the dozens of instances where Garshin is described by 
a critic, in a translator's preface, or as part of some other paratext. Over and over again we find Garshin framed through his bouts with mental illness and his eventual suicide in a way that present his fiction, in particular "The Red Flower," as a literary key for unlocking the realities of acute neurosis and insanity. Other reasons are given for appreciating his work, of course, but from the start there is an obsession with the biographical fact of his having gone mad. We find it in the preface to Tanizaki's 1914 translation and an accompanying newspaper advertisement; in a 1927 volume on Russian literary history that recasts his "fragile and sensitive nature" as a sacrificial martyrdom to the violence of modern society; and again in the commentary of his translators in the 1930s, who further reinforce the martyr narrative and the impulse to read "The Red Flower" autobiographically. ${ }^{97}$ Symptomatic readings of this sort would continue into the postwar period as even more translations of his collected works entered the market. ${ }^{98}$

This repetitiveness can partly be attributed to the brevity of Garshin's life and the small size of his literary footprint, which facilitate easy condensation into a few select traits. Several of these traits, in particular the image of him as a Christ-like martyr able to absorb the darkness and evil of his time, have their origins in an essay by the poet D.S. Merezhkovsky from 1893. This essay also memorialized Garshin as a writer who could squeeze the complex stuff of the world down to its essence and deliver this straight to the hearts of his readers through concentrated symbols. These served as a stimulant, or even a poison, distilled from the inexplicable doubts that had plunged Garshin himself into madness. ${ }^{99}$ Merezhkovsky fed the popularized image of Garshin as a medium of mass psychogenic contagion, whose sensitivity to the world is such that it opens up an affective channel to which others can attune themselves. This image of Garshin as a sensitive receiver carries over into his reception in Japan, if more subtly. Garshin's heightened sensitivity allows him to make visible a wider set of associations around the objects he depicts, as if one was "hearing the sea through a shell found far inland"; to "directly and without embellishment touch and enter into the essence of things"; to "spur the cold hearts of people, rousing them from slumber and blowing love into their hearts"; "to directly perceive the pain of others"; to nurture "an extraordinarily polished moral sensitivity"; and to function like a "highly sensitive radio or delicate machine" that picks up on emotions or feelings invisible to others. ${ }^{100}$ Judged against these repeated allusions to Garshin's sensitivity and his capacity for provoking affective response, 
Yamanoi's own pathological reading, framed by his experience with mental illness, looks increasingly like the most predictable response. Contingency at the individual level becomes predestination at the collective level as Yamanoi taps into a mass psychogenic hallucination gone global - a co-incidence of contingencies operating as a sort of provisional stability or noncontingency against which any initial wagers about his relative value must be reassessed. ${ }^{101}$ Yamanoi's encounter is miraculous and predictable all at once.

\section{Foregone Conclusions}

This final thought experiment brings us back to the familiar work of literary history. Yet we return via a detour through modes of probabilistic reasoning meant to defamiliarize this work as a simple binary choice between packing history into tidy, determinist containers (i.e., the contextualist paradigm) or throwing all predictability to the wind. A detour, moreover, meant to rethink this dichotomy as a productive tension or negotiation between different heuristics for judgments under uncertainty. All disciplines have wrestled with this tension for the better part of two centuries in response to radical changes in their surrounding information environments. As methods for recording and analyzing data have evolved across different fields of knowledge, they have reshaped the ways that chance is perceived and spurred intense debate over how to reconcile objective observations with subjective belief and experience. In fields like literary history, where the latter is often the locus of interpretation, this debate can morph into a polemic against the seductive pull of statistical rules and computational instruments that promise to read the past for evidence of patterns. Such patterns, it is insisted, obscure "human scrappiness" and individual difference, or lack the complex subtleties of personal judgment (which, it bears repeating, has its own internalized, often unconscious habits of pattern recognition). The debate is an ongoing and necessary one, especially at a time when massive new data stores mined by super-charged predictive algorithms induce fantasies of taming chance absolutely even as they amplify the worst biases of human judgment. ${ }^{102}$ My own detour through probabilistic reasoning has attempted to illustrate that the debate has always involved an implicit negotiation between competing heuristics, not a total subsumption of one by another. What might (world) literary history gain if it more deliberately shuttled between these heuristics rather than picked sides? 
This essay has provided but one possible model of what such a history might look like. If certain aspects of this model resemble recent work in book history, it is because it participates in the latter's elevation of "contingency" as an analytically and rhetorically useful concept. Nan Z. Da attributes this elevation, in part, to the semantic flexibility of the word, which allows it "to 'scale' from situational variation...to larger uncertainties within populations over time"; from individual encounters with books to the collective phenomena revealed by bibliographic data sorted geographically. Larger scales, however, mean increased adoption of social scientific concepts (e.g., variation and spread, spatial distribution patterns, models of dispersal) and consequently, in Da's estimation, a severe narrowing of "the meaning of contingency down to either completely isolated circumstance or combinatorial chance." 103 The result of this narrowing is a reductive sociology of reading that overlooks the open-endedness of encounters with books and all the ways that their "imprint on a life...does not translate into external signs." Applied to world literature, this sociology can slide into a "cultural essentialism" that treats the bibliographic currents unique to non-Anglo-European readerships as having total explanatory power over their reading lives - a discrete branch in the river leading to an alternative universe all the more exotic for being the one not taken at the centers of global cultural hegemony. ${ }^{104}$

For $\mathrm{Da}$, the final lesson here is that the "empirical assessments of reading and book use" must be rounded out by other approaches that "reemphasize the opacity of a reader's interactions with books that she might read with absorption or not: once but thoroughly; or over long periods of time, but distractedly; or repeatedly, to different effects." I could not agree more. At the scale of individual lives and readers, where so much evades capture by the historical record, it feels safest to bet, like $\mathrm{Da}$, on the "indeterminacy" of all that readers do with books. ${ }^{105}$ The anecdotal accounts by Akutagawa or Katai or Yamanoi may themselves be an evasion of sorts, an attempt to control the narratives of their reading lives. Do the empirical traces of bibliomigrancy really matter if Yamanoi was simply entranced by his own conspiratorial designs, seeing in "The Red Flower" all the contingencies of his life linked together? He is like the story's narrator, someone who sees in any object "all its history" and for whom the world's evils accumulate in the scarlet petals of a tiny poppy. ${ }^{106}$ Yet how then to disentangle his or any account from our own? Where does 
the "rounding out" of empirical assessments with indeterminacy turn into its own kind of conspiratorial vision and own kind of blindness to the subjective biases and preconceptions we bring to interpretations of the past? Conversely, if empirical assessments are a way to relativize these biases, no matter that they introduce their own, at what distance are they most helpful for relating use value to exchange value, human scrappiness to collective regularity? These are open and irresolvable questions. As I have tried to show, however, there are deeper conceptual reservoirs from which to address them before circling around, once more, to indeterminacy as the final explanans of how books travel and acquire meaning.

As my experiments in probabilistic thinking illustrate, judgment under uncertainty has always been a more nuanced epistemological project than merely reducing contingency to a fork in the road. Although I have only scratched the surface of how such thinking has evolved over time, we have seen enough to recognize it is an ongoing and unsettled project - an assemblage of tendencies rather than a single totalizing system. Within this assemblage we find competing ideas about how to reconcile empirical observation with subjective knowledge, group-level regularities with individual stochasticity, probabilistic rules with cognitive heuristics. But we also find in it a place for thinking the improbable and unexpected, a region existing in productive tension with other worlds of probabilistic thought. ${ }^{107} \mathrm{How}$, indeed, can the former be imagined without reference to the latter? And yet the appeals to indeterminacy in literary history tend to leave the impression that it is an isolated exclusion zone, a world closed off unto itself.

This essay has considered what (global) literary history gains by opening the gates between these worlds when reasoning across the gap between fate and random chance. By using empirical data, for instance, as a form of "baseline thinking" that recalibrates our perception of what is novel or unexpected, and which becomes more relevant as expanding digital archives allow for the construction of baselines at new scales. ${ }^{108}$ By recognizing, moreover, that such thinking is not a means to override indeterminacy, but to explicate it in a more granular way, whether across different scales of evidence, different bodies of evidence, or in negotiation with the beliefs and heuristics we bring to our judgments under uncertainty. The point of this negotiation is not so that we can all arrive at the same place; there will always be disagreement over the suitability of certain base rates for certain scenarios and, at a 
more fundamental level, everyone arrives at a problem along different paths of prior belief and knowledge. Nevertheless, to the extent that engaging with probabilistic reasoning can help delineate and externalize the process that gets us to a particular judgment, it turns indeterminacy and the unexpected into a matter of open, collective debate rather than a foregone conclusion. Looking back to Akutagawa scanning Maruzen's shelves; or to Katai as he rummaged through bookseller's catalogs; or to Yamanoi as he perused the Nikolai Cathedral's library stacks, such reasoning is a way to navigate the vast space of historical uncertainty that lies between the total novelty of a reader's world and external contexts that threaten to reduce this world of infinite possibility to a single dimension. A space akin, perhaps, to that separating the patient in Garshin's tale, who sees entire worlds unfold in his tiny red flowers, from the doctors who look on, seeing only a deranged man whose psychosis has led him to trample wildly through the hospital garden.

\title{
References
}

\begin{abstract}
${ }^{1}$ This essay was originally conceived for the "Novel Worlds" conference held in Montreal, Canada, in the fall of 2018. I want to thank the workshop's participants for their feedback, as well as the two anonymous reviewers who commented on the essay in its final stages. The essay also benefitted from conversations with Heekyoung Cho, Jonathan Zwicker, Paola Iovene, and Shun'ichirō Akikusa. I am especially grateful to Philomena Mazza-Hilway and Simone Oliver for helping to digitize and clean the bibliographic datasets.
\end{abstract}

${ }^{2}$ See Jonathan Zwicker, Practices of the Sentimental Imagination: Melodrama, the Novel, and the Social Imaginary in Nineteenth-Century Japan (Cambridge, MA: Harvard University Asia Center, 2006); Edward Mack, Manufacturing Modern Japanese Literature: Publishing, Prizes, and the Ascription of Literary Value (Durham, NC: Duke Univeristy Press, 2010); Nathan Shockey, The Typographic Imagination: Reading and Writing in Japan's Age of Modern Print Media (New York: Columbia University Press, 2019); Kōno Kensuke, Shomotsu no kindai: media no bungaku-shi (Chikuma Shobō, 1992); and Nagamine Shigetoshi, Modan toshi no dokushō kūkan (Nihon Editā Sukūru Shuppanbu, 2001).

${ }^{3}$ Akutagawa Ryūnosuke, “Jidai” (The Age), in Akutagawa Ryūnosuke zenshū, vol. 9 (Iwanami Shoten, 1977-78): 310. All translations are my own unless otherwise noted.

${ }^{4}$ Seiji Lippit offers one such reading in Topographies of Japanese Modernism (New York: Columbia University Press, 2002), 51-52.

${ }^{5}$ In particular, see David Damrosch's work on the anthologization and canonization of world literature in the context of higher education in What is World Literature? (Princeton, NJ: Princeton University Press, 2003); Gisèle Sapiro's work on the role of publishers and translators in shaping the dynamics of transnational literary markets in "Globalization and Cultural Diversity in the Book Market: The Case of Literary Translations in the US and in France," Poetics 38 (2010): 419-439, and "How do Literary Works Cross Borders (or Not)?," Journal of World Literature 1, no. 1 (2016): 81-96; and Priya Joshi's account of libraries as mediating agents in the reception of English and other literatures in colonial India in In Another Country: Colonialism, Culture, and the English Novel in India (New York: Columbia University Press, 2002). 
${ }^{6}$ B. Venkat Mani, Recoding World Literature: Libraries, Print Culture, and Germany's Pact with Books (New York: Fordham University Press, 2017), 9-47.

${ }^{7}$ Cited in Mani, 150.

${ }^{8}$ Mani, 150.

${ }^{9}$ Joseph North, Literary Criticism: A Concise Political History (Cambridge, MA: Harvard University Press, 2017), 1.

${ }^{10}$ Rita Felski, The Limits of Critique (Chicago: University of Chicago Press, 2015), 156.

${ }^{11}$ Felski, 162.

${ }^{12}$ Felski, $170-71$.

${ }^{13}$ Caroline Levine, Forms: Whole, Rhythm, Hierarchy, Network (Princeton, NJ: Princeton University Press, 2015), 104.

${ }^{14}$ Ian Hacking, The Taming of Chance (Cambridge: Cambridge University Press, 1990), 148.

${ }^{15}$ Cited in Hacking, 146.

${ }^{16}$ Hacking, 215.

${ }^{17}$ Eric Hayot makes this point eloquently and extensively in Humanist Reason: A History. An Argument. A Plan (New York: Columbia University Press, 2021). He shows how the division of the idiographic and the nomothetic in literary studies, and humanistic reasoning more generally, has its roots in the rise of statistics and other quantitative disciplines in the nineteenth-century. This epistemological division, which maps onto divisions between event and law, freedom and necessity, the particular and the general, is lodged at the core of how literary studies sees itself both as method and ethical stance. Andrew Piper has also written on how scholars in the humanities have resisted the probabilistic thinking that penetrated other fields of knowledge in the nineteenth century, the legacy of which is an impoverished language of generalization and a too ideal notion that "generalizing" is not what we do. See Can we be Wrong? The Problem of Textual Evidence in a Time of Data (Cambridge: Cambridge University Press, 2020). If literary studies as a discipline has tended to shy away from probabilistic thinking, several scholars have written on how it impacted literature itself. See Rüdiger Campe, The Game of Probability: Literature and Calculation from Pascal to Kleist (Stanford, CA: Stanford University Press, 2012); Maurice Lee, Uncertain Chances: Science, Skepticism, and Belief in Nineteenth-Century American Literature (New York: Oxford University Press, 2012); and Adam Grener, Improbability, Chance, and the Nineteenth-Century Realist Novel (Columbus, OH: The Ohio State University Press, 2020).

${ }^{18}$ Tayama Katai, Tokyo no sanjūnen, 1917 (Kadokawa Shoten, 1955), 160-61. Odd Number refers to a collection of English translations produced by Jonathan Sturges and published in 1889. Emphasis mine.

${ }^{19}$ Katai, 161 . The series Katai purchased is likely one published in the 1890 s by London's Mathieson \& co. as part of their "after-dinner series."

${ }^{20}$ James Hadley, “The Beginnings of Literary Translation in Japan: An Overview,” Perspectives 26, no. 4 (July 2018): 568.

${ }^{21}$ Katai, 160.

${ }^{22}$ Meiji-ki hon'yaku bungaku sōgō nenpyō, in Meiji hon'yaku bungaku zenshū, vol. 52, Kawato Michiaki, et al., eds. (Ōzorasha, 2001). While the volume contains additional metadata for each title, only the publication year and author country were collected for this study as it had to be done manually. 
${ }^{23}$ Meiji $\cdot$ Taishō $\cdot$ Shōwa hon'yaku bungaku mokuroku, ed. Kokuritsu Kokkai Toshokan (Kazama Shobō, 1959).

${ }^{24}$ Overall publication numbers are taken from Shuppan nenkan, an annual trade journal that republished government statistics on publishing trends. The truncated time frame is due to these statistics not beginning until 1881 and going unrecorded from 1943 to 1949 . The Meiji period statistics include newspapers and magazines in the yearly totals, while only books are included after 1912. Ideally, one should calculate these percentages based on discrete volumes, and not on individual translations. However, the Diet Library index cannot be aggregated to the volume level without further manual correction of the digitized data.

${ }^{25}$ Jay Rubin, Injurious to Public Morals: Writers and the Meiji State (Seattle, WA: University of Washington Press, 1984), 199-212.

${ }^{26}$ Ōta Saburō, "Hon'yaku bungaku," in Iwanami kōza nihon bungaku-shi, vol. 14 (Iwanami Shoten, 1959). His graph, based on records at the Ueno Library and Japan PEN Club, shows a similar decline in translation during the teens.

${ }^{27}$ The previously cited work of Joshi and Sapiro are exemplary in this regard. For Japan, see especially work by Zwicker, Hadley, and Heekyoung Cho, Translation's Forgotten History: Russian Literature, Japanese Mediation, and the Formation of Modern Korean Literature (Cambridge, MA: Harvard University Asia Center, 2016).

${ }^{28}$ Joshi, 28.

${ }^{29}$ On the history of probabilistic reasoning, see Hacking; Lorraine Daston, Classical Probability in the Enlightenment (Princeton, NJ: Princeton University Press, 1988); Gerd Gigerenzer, et al., eds., The Empire of Chance: How Probability Changed Science and Everyday Life (Cambridge, UK: Cambridge University Press, 1989). Lee offers a concise summary of this scholarship in Uncertain Chances, 14-27.

${ }^{30}$ The scholarship warning against the harms of predictive algorithms for society has grown exponentially in the last several years. Canonical touchstones include Cathy O'Neil, Weapons of Math Destruction: How Big Data Increases Inequality and Threatens Democracy (New York: Crown, 2016); Virginia Eubanks, Automating Inequality: How High-Tech Tools Profile, Police, and Punish the Poor (New York: St. Martin's Press, 2018); and Ruha Benjamin, Race after Technology: Abolitionist Tools for the New Jim Code (Cambridge, UK: Polity Press, 2019).

${ }^{31}$ Hayot, 47.

${ }^{32}$ Lee, 9.

${ }^{33}$ Barbara Herrnstein Smith, Contingencies of Value: Alternative Perspectives for Critical Theory (Cambridge, MA: Harvard University Press, 31-32).

${ }^{34}$ Hume believed that any certainty about the world is based on our own experience. Thus the probability of a miracle is zero as we have no prior experience of it. On Hume's "Essay on Miracles," see Empire of Chance, 26-29.

${ }^{35}$ Smith, 149. Eric Hayot suggests that such methodological statements, which insist on the singularity of the aesthetic object and aesthetic experience, are almost always a ruse. Almost no one follows through on such proposals because to do so would be to reject the idea that aesthetic objects have a social function at all, and would necessitate matching every object with a singular method. See Humanist Reason, 80-81.

${ }^{36}$ Empire of Chance, 29.

${ }^{37}$ Daston, 238.

${ }^{38}$ Daston, 231.

${ }^{39}$ Daston, 238. 
${ }^{40}$ Empire of Chance, 30.

${ }^{41}$ Daston, 257. Daston draws here on Richard Price's interpretation of Bayes's work.

${ }^{42}$ Sharon Bertsch McGrayne, The Theory that Would Not Die (New Haven, CT: Yale University Press, 2011 ), 20.

${ }^{43}$ Daston, 273-74.

${ }^{44}$ McGrayne, 31-32.

${ }^{45}$ Akikusa Shunichirō, “Jutsugo toshite no 'sekai bungaku': 1895-2016,” Bungaku 17, no. 5 (September 2016 ), 10.

${ }^{46}$ Mary Hammond, Reading, Publishing, and the Formation of Literary Taste in England, 1880-1914 (Aldershot, England: Ashgate, 2006), 94.

${ }^{47}$ Hammond, 91-92.

48 The ad, which was unprecedented at the time, was created by series editor Satō Giryō. See Obi Toshito, Shuppan to shakai (Genki Shobō, 2007), 198-99.

${ }^{49}$ Books published in the Everyman's series are listed in A.J. Hoppé, The Reader's Guide to Everyman's Library (London: Dent, 1960).

${ }^{50}$ Obi, 198-99.

${ }^{51}$ Obi, 195.

${ }^{52}$ Hammond, 106-107.

53 This $60 \%$ figure was generated by cross-referencing each title with the National Diet Library index.

${ }^{54}$ Obi, 201-202.

${ }^{55}$ In fact, the scenario I have constructed here violates assumptions that are necessary to calculating an actual probability, including the assumption of independence of causes and their constancy over time.

${ }^{56}$ More technically, a significant p-value means that there is evidence to reject the null hypothesis: that the coefficients in the linear models fit to each subsample are equal, and thus a model fit to the entire sample would perform just as well. To determine the p-value, the sum of squared residuals of each of the fitted models (on the whole sample and the two subsamples) are combined to produce the Chow statistic, which is then compared to a test statistic from the F distribution based on number of parameters and sample size.

${ }^{57}$ This data was collected from a catalog of books selected by the Association. See Nihon toshokan kyōkai sentei tosho mokuroku, ed. Nihon Tosho Kyōkai (Nihon Tosho Kyōkai Henshūbu, 1918), 90-148. Although the literature selections were mostly comprised of works by American and European authors, several classical Chinese and Arabic works were also recommended.

${ }^{58}$ Empire of Chance, 35.

${ }^{59}$ McGrayne, 31.

${ }^{60}$ Daston, 299.

${ }^{61}$ Empire of Chance, 41-42. Daston, 294.

${ }^{62}$ Hacking, 112, 75-79. 
${ }^{63}$ For a complete list of contributing libraries, see http://viaf.org. Detailed descriptions of VIAF and its origins are available in Anila Angjeli, Andrew Mac Ewan, and Vincent Boulet, "ISNI and VIAF - Transforming Ways of Trustfully Consolidating Identities" (2014): DOI: 10.13140/RG.2.1.1350.8640; and Françoise Bourdon and Vincent Boulet, "VIAF: A Hub for Multilingual Access to Varied Collections" (2011):

http://conference.ifla.org/past/ifla77/79-bourdon-en.pdf.

${ }^{64}$ Personal communication with Matt Erlin, September 2020.

${ }^{65}$ Because the data does not include reliable information on individual volumes, I could not filter on volume alone. Nevertheless, the hope is that even for collections of works, selecting just the unique author-translator strings will cancel out volumes with identical contents.

${ }^{66}$ To determine how different a volume-based count would be from the NDL index, I produced a volume-based count from the Diet Library's current holdings for all translated volumes by the top 50 authors in the index (published between 1912 and 1955). How does the index, in other words, compare with the volumes recorded in the library's current catalog? This process yielded a ranked list which I compared to the index ranking using a modified Kendall's tau statistic, which accounts for ties in the ranking. The two rankings have a correlation of .39 (1 indicates perfect correlation), suggesting a fairly low correspondence between the title and volume-based counts in terms of the rank order.

${ }^{67}$ The adjustment was made by estimating the overall percentage of non-literary works from three weighted random samples. Each sample of 100 entries was manually categorized as either literature or not. The mean percent of nonliterary texts across all three samples was $13.6 \%$.

${ }^{68}$ The Russian Impact on Japan Literature and Social Thought (1981), 113. They also counted volumes from the Meiji Period, which come from a section of the Diet Library index that I was unable to digitize for this study.

${ }^{69}$ On Tolstoy's deep influence on political thought in Japan, see Sho Konishi, Anarchist Modernity: Cooperatism and Japanese-Russian Intellectual Relations in Modern Japan (Cambridge, MA: Harvard University Press, 2013). On Tolstoy's literary influence in both Japan and Korea, see Cho, Translation's Forgotten History.

${ }^{70}$ The idea of caprice as a more rational response to prediction under uncertainty comes from John Maynard Keynes's work on probability, cited in Simon DeDeo, "Bayesian Reasoning for Intelligent People" (August 2018): https://wiki.santafe.edu/images/2/2e/Bayesian-Reasoning-for-Intelligent-People-DeDeo.pdf, 9.

${ }^{71}$ DeDeo provides a lucid explanation of how objective frequencies are incorporate into the Bayesian framework in "Bayesian Reasoning for Intelligent People," 2-3.

${ }^{72}$ The resurgence of Bayesian statistics in the postwar period was initially fueled by its application in the military and insurance industry. See McGrayne, Parts II and III. For a history of how statistics came to inform theories of mind in the 1960s, in part as a result of its broader institutionalization in the social sciences, see Empire of Chance, ch. 6 .

${ }^{73}$ Amos Tversky and Daniel Kahneman, “Judgment Under Uncertainty: Heuristics and Biases,” in Judgment Under Uncertainty: Heuristics and Biases, ed. Amos Tversky, et al. (Cambridge: Cambridge University Press, 1982), 3. The essay was originally published in Science in 1974.

${ }^{74}$ On the specific concept of "representativeness," see Tversky and Kahneman, "On the Psychology of Prediction," in Judgment Under Uncertainty, 48-68. The essay originally appeared in Psychological Review in 1973.

75 These heuristics are all fully described in Tversky and Kahneman, "Judgment Under Uncertainty: Heuristics and Biases."

${ }^{76}$ Tversky and Kahneman were also cognizant of the difference between these two ideas of prediction and were careful not to conflate one with the other. As Persi Diaconis and Brian Skyrms write, the two concluded "that the 
psychological, descriptive theory of choice and the logical, prescriptive theory of choice are two different enterprises. The prescriptive theory - the logic — is expected utility theory and an adequate descriptive theory must run a gamut of systematically observable deviations from it. This does not mean that people cannot learn the logic and implement it in situations where it is important to do so and there is enough time to think carefully." See Ten Great Ideas about Chance (Princeton, NJ: Princeton University Press, 2018), 57.

${ }^{77}$ Smith, 42.

${ }^{78}$ John Guillory, Cultural Capital: The Problem of Literary Canon Formation (Chicago: University of Chicago Press, 1993), 324-25.

${ }^{79}$ Guillory, 295.

${ }^{80}$ Guillory, 288.

${ }^{81}$ Guillory, 299. Emphasis in original.

${ }^{82}$ Yamanoi Aitarō, “Garushin no ‘Akai hana’ to watashi,” Rinshō keirin 2, no. 2 (1940), 60.

${ }^{83}$ See Peter Henry, A Hamlet of his Time: Vsevolod Garshin: The Man, his Works, and his Milieu (Oxford: Willem A. Meeuws, 1983), 7-14.

${ }^{84}$ Henry, 161-62.

${ }^{85}$ As described in Robert D. Wessling, "Vsevolod Garshin, the Russian Intelligentsia, and Fan Hysteria," in Madness and the Mad in Russian Culture, ed., Angela Brintlinger and Ilya Vinitsky (Toronto: University of Toronto Press, 2006), 75.

${ }^{86}$ Henry, 15, 229.

${ }^{87}$ Wessling, 76.

${ }^{88}$ Yamanoi, 64.

${ }^{89}$ As the authors of Empire of Chance write, the question of how people arrive at a base rate suitable to the prediction task at hand was "rarely considered a topic for research into judgment under uncertainty." And yet it is obvious that individuals "must sift information for potentially relevant variables and decide to what variable(s) the base rate should refer. There is no single correct or mechanical solution to this question; it is a matter of informed judgment." See Empire of Chance, 230-231. Emphasis mine.

${ }^{90}$ Henry, 341, fn. 53.

${ }^{91}$ Henry, 15-16.

${ }^{92}$ Henry, 339, fn. 32. See also Rachel May, The Translator in the Text: On Reading Russian Literature in English (Evanston, IL: Northwestern University Press), 20-31.

${ }^{93}$ W.M. Garshin, The Signal and Other Stories, trans. Captain Rowland Smith (London: Duckworth \& Co., 1912).

${ }^{94}$ Garshin, Akai hana, trans. Tanizaki Seiji (Kaigai Bungeisha, 1914). The book was the $8^{\text {th }}$ volume in the Kaigai bungei sōsho series. This anthology of "overseas literature" was not the first of its kind, as the mass-market publisher Hakubunkan had earlier published a 12 volume "Modern Western Literature" series. But it is notable for being a more upscale version of the latter and for its decided preference for Russian authors (Andreyev, Gorky, Tolstoy, and Garshin). For a description, see Kōno Toshirō, "Taishō-ki no 'Bungei sōsho' - 'Kaigai bungei sōsho'," Nihon kosho tsüshin, no. 763 (February 1993), 19-21. It should be noted that this was not Garshin's first appearance in Japanese translation. The famous novelist and Russian translator Futabatei Shimei had already translated three of 
his stories for the literary magazine Shinshōsetsu and the Tokyo Asahi newspaper between 1904 and 1906. "The Red Flower" was not among them, but it was through Futabatei's translations that Japanese writers first came to know of Garshin. Tanizaki likely came to know of him through his affiliation with the "Waseda Group" (Waseda-ha), a small coterie linked to Waseda University's English Department, and which included Hirotsu Kazuo and Kasai Zenzō. As Heekyoung Cho notes, the department was a crucial intermediary for students wanting to study Russian literature in the early teens (39-40). Several in the group, including Tanizaki, also belonged to the Kiseki-ha, or Miracle Group, a literary coterie invested in works depicting psychological anguish and neurosis. See Hoshino Yukihiko, "Garushin to Kiseki-ha," Kaishaku 28, no. 10 (1982): 38-41.

95 The three volumes were Okubyōsha to yokkakan, trans. Kimura Sōgo (Kōnosha, 1920); Garushin zenshū, trans. Takasaki Tōru, 3 vols. (Shunyōdō, 1933); and Akai hana: hoka yonhen, trans. Jinzai Kiyoshi (Iwanami Bunko, 1937). On the history of Iwanami Bunko pocket paperbacks, see Shockey, ch. 2.

${ }^{96}$ The literature primer contained Futabatei Shimei's translation of "Four Days." Kindai Nhion bungei dokuhon, ed. Akutagawa Ryūnosuke, vol. 2 (Kōbunsha, 1925). The short story anthology contained a translation of "The Red Flower" by Uchiyama Kenji. Sekai tanpen shōsetsu taikei: Roshia hen, vol. 1 (Kindaisha, 1925).

${ }^{97}$ See the previously cited translations by Tanizaki, Takasaki, and Jinzai. The ad for the Tanizaki translations appeared in the Tokyo asahi shinbun, February 11, 1914, morning edition, p. 1. On his "fragile and sensitive nature" as a kind of sacrificial martyrdom, see Yamauchi Keisuke, Roshiya bungaku-shi (Kinseidō, 1927), 191-92.

${ }^{98}$ Between 1947 and 1949, a 4 volume set of selected works was published as part of a much larger world literature series. This was followed in 1950 by a 2 volume collected works. See Garushin sensh $\bar{u}$, trans. Konuma Fumihiko (Sekai Bungakusha, 1947-1949) and Garushin zensh $\bar{u}$, trans. Nakamura Tōru (Sōgeisha, 1950). The latter was reissued in 1952 and translations from both would be republished in various formats throughout the early 1950s, including one version of "The Red Flower" issued as part of an anthology of world literature for young girls and boys. A critical essay from 1948 is emblematic of the continued symptomatic reading of this story, where it is read alongside Chekov's "Ward No. 6" in order to theorize a "literature of the mad." Ara Masahito, "Kyōjin bungakuron," Kosei 1, no. 12 (1948): 10-19.

${ }^{99}$ The essay was partially translated into Japanese in 1934 as "Garushin ni kansuru nōto," trans. Katō Shinya, Mita bungaku 9, no. 8 (1934): 86-89. The original Russian title of the essay is O prichinakh upadka i o novykh techeniyakh sovremennoy literatury ("On the causes of the Decline and on the New Trends in Contemporary Russian Literature").

100 These quotes come from Baba Kochō, Kindai bungei no kaibatsu (Kobundō Shoten, 1914), 176; Okubyōsha to yokkakan, 2; Yamauchi, 191; Garushin zenshü (1933), vol. 3, 3; Akai hana: hoka yonhen, 124; and Akai hana, trans. Nakamura Tōru (Seibunkaku, 1951), 195.

101 The idea of "provisional stability" comes from Smith, who tries at one point to walk a finer line between contingency and pattern in delineating the irreducible scrappiness of humans. She argues that the relations among our actions, knowledge, beliefs, goals, and interests "consist of continuous interactions among various structures, mechanisms, traces, impulses, and tendencies that are not necessarily...consistent, coordinated, or synchronized...It must be added, however, that although these interactions obey no 'rule' and have no 'reason,' they do nevertheless operate reliably enough under recurrent conditions to permit their more or less coherent description through various modes of reflexive....analysis and also yield local resolutions and provisional stabilities" (148).

${ }^{102}$ For an illuminating reflection on new forms of determinism produced by deep-learning algorithms, see Alexander Campolo and Kate Crawford, "Enchanted Determinism: Power Without Responsibility in Artificial Intelligence," in Engaging Science, Technology, and Society 6 (2020): 1-19.

${ }^{103}$ Nan Z. Da, “Other People’s Books,” New Literary History 51, no. 3 (Summer, 2020): 475-76.

${ }^{104} \mathrm{Da}, 489,480-81$.

${ }^{105} \mathrm{Da}, 490$. 
${ }^{106}$ I draw here on the English translation of "The Red Flower" by Liv Tudge, included in From the Reminisces of Private Ivanov and other stories (London: Angel Books, 1988), 203.

${ }^{107}$ An insightful introduction to the "highly improbable" as philosophical and statistical problem can be found in Nassim Nicholas Taleb, The Black Swan: The Impact of the Highly Improbable (New York: Random House Trade Paperbacks, 2007).

${ }^{108}$ For a recent example of the power of bibliographic baselines to recalibrate entrenched literary historical beliefs, see Richard Jean So, Redlining Culture: A Data History of Racial Inequality and Postwar Fiction (New York: Columbia University Press, 2021). So makes a convincing case for how basic descriptive statistics (e.g., that $97 \%$ of the authors published at Random House between 1950 and 2000 were white) can aid in how we read individual authors and texts against large-scale structural inequalities. Allen Riddell and Michael Betancourt also make the case for better bibliographic baselines in their recent "Reassembling the English Novel, 1789-1919," Journal of Cultural Analytics (February 3, 2021): https://doi.org/10.22148/001c.19102. They estimate yearly rates of new novel production across this period in order to aid in sociological understanding of those who pursued careers as novelists. 